OPEN ACCESS

Edited by: Graziano Fiorito, Stazione Zoologica Anton Dohrn, Italy

Reviewed by:

Daniel Wangpraseurt, University of Copenhagen, Denmark

Susana Enríquez,

Universidad Nacional Autónoma de

México, Mexico

*Correspondence:

Thomas D. Hawkins tom.hawkins.photo@gmail.com; Mark E. Warner mwarner@udel.edu

Specialty section: This article was submitted to Invertebrate Physiology, a section of the journal

Frontiers in Physiology

Received: 16 December 2015 Accepted: 22 March 2016

Published: 18 April 2016

Citation

Hawkins TD, Hagemeyer JCG, Hoadley KD, Marsh AG and Warner ME (2016) Partitioning of

Respiration in an Animal-Algal Symbiosis: Implications for Different Aerobic Capacity between Symbiodinium spp.

Front. Physiol. 7:128

doi: 10.3389/fphys.2016.00128

\section{Partitioning of Respiration in an Animal-Algal Symbiosis: Implications for Different Aerobic Capacity between Symbiodinium spp.}

\author{
Thomas D. Hawkins *, Julia C. G. Hagemeyer, Kenneth D. Hoadley, Adam G. Marsh and \\ Mark E. Warner*
}

College of Earth, Ocean and Environment, School of Marine Science and Policy, University of Delaware, Lewes, DE, USA

Cnidarian-dinoflagellate symbioses are ecologically important and the subject of much investigation. However, our understanding of critical aspects of symbiosis physiology, such as the partitioning of total respiration between the host and symbiont, remains incomplete. Specifically, we know little about how the relationship between host and symbiont respiration varies between different holobionts (host-symbiont combinations). We applied molecular and biochemical techniques to investigate aerobic respiratory capacity in naturally symbiotic Exaiptasia pallida sea anemones, alongside animals infected with either homologous ITS2-type A4 Symbiodinium or a heterologous isolate of Symbiodinium minutum (ITS2-type B1). In naturally symbiotic anemones, host, symbiont, and total holobiont mitochondrial citrate synthase (CS) enzyme activity, but not host mitochondrial copy number, were reliable predictors of holobiont respiration. There was a positive association between symbiont density and host CS specific activity (mg protein ${ }^{-1}$ ), and a negative correlation between host- and symbiont CS specific activities. Notably, partitioning of total CS activity between host and symbiont in this natural E. pallida population was significantly different to the host/symbiont biomass ratio. In re-infected anemones, we found significant between-holobiont differences in the CS specific activity of the algal symbionts. Furthermore, the relationship between the partitioning of total CS activity and the host/symbiont biomass ratio differed between holobionts. These data have broad implications for our understanding of cnidarian-algal symbiosis. Specifically, the long-held assumption of equivalency between symbiont/host biomass and respiration ratios can result in significant overestimation of symbiont respiration and potentially erroneous conclusions regarding the percentage of carbon translocated to the host. The interspecific variability in symbiont aerobic capacity provides further evidence for distinct physiological differences that should be accounted for when studying diverse host-symbiont combinations.

Keywords: cnidarian-dinoflagellate symbiosis, zooxanthellae, citrate synthase, mitochondria, reef coral, Exaiptasia pallida, Aiptasia, CZAR 


\section{INTRODUCTION}

Symbioses in which one partner (the symbiont) resides within the cells of a larger host organism to form a "holobiont" (used here as the host-symbiont unit) are widespread and contribute significantly to the success of some important biological groups (Douglas, 2010). One well-studied symbiosis involves cnidarians and photosynthetic dinoflagellates (genus Symbiodinium). Symbiotic cnidarians benefit significantly from the organic carbon generated by algal symbiont photosynthesis, while the algae benefit from access to host-derived nutrients (Muscatine, 1990; Muller-Parker and D’Elia, 1997; Yellowlees et al., 2008; Davy et al., 2012). This nutritional exchange underpins the success of scleractinian corals and, therefore, supports the high productivity and biodiversity of coral reefs (Muscatine and Porter, 1977; Muller-Parker and D'Elia, 1997). Despite much research effort, we lack a full understanding of metabolic interactions between the two partners (see Davy et al., 2012 for review) and how these interactions vary between different cnidarian-Symbiodinium associations (Steen and Muscatine, 1984; Hoegh-Guldberg and Smith, 1989; Verde and McCloskey, 1996; Stat et al., 2008; Starzak et al., 2014; Leal et al., 2015).

In optimal environments, intracellular Symbiodinium can provide a host with a significant portion of its daily respiratory carbon requirements (Muscatine et al., 1981; Falkowski et al., 1984; Muscatine, 1990; Verde and McCloskey, 1998; MullerParker and Davy, 2001 for review). However, estimates of how much photosynthetically fixed carbon is provided to the host and, implicitly, how much is retained by the algal symbionts, have depended largely on the use of two methods. The first measures photosynthetic fixation of ${ }^{14} \mathrm{C}$ - or ${ }^{13} \mathrm{C}$-bicarbonate and its subsequent translocation into host tissues (Trench, 1971; Hofmann and Kremer, 1981; Muscatine et al., 1984; Gattuso et al., 1993; Davy and Cook, 2001; Hughes et al., 2010; Tremblay et al., 2012, 2014; Hoadley et al., 2015; Kopp et al., 2015). The second technique, known as the "growth rate method," relies on measurements of light- and dark oxygen fluxes alongside estimations of in-hospite symbiont growth rates and carbon contents (usually inferred from mitotic indices and cell volumes, respectively) to estimate the contribution of zooxanthellae (=Symbiodinium) to animal respiration (commonly abbreviated as CZAR) (Muscatine et al., 1981, 1983; McCloskey and Muscatine, 1984). This method has been applied more widely than have the ${ }^{14} \mathrm{C}$ or ${ }^{13} \mathrm{C}$ methods, presumably due to the relative ease with which oxygen fluxes can be measured (Fitt et al., 1982; Muller-Parker, 1984; Muscatine et al., 1984; Steen and Muscatine, 1984; Davies, 1991; Davy et al., 1996; Verde and McCloskey, 1996; Fitt and Cook, 2001; Grottoli et al., 2006; Starzak et al., 2014). However, both methods have specific limitations. The ${ }^{14} \mathrm{C}$ and ${ }^{13} \mathrm{C}$ methods do not account for the loss of activity from the system as $\mathrm{CO}_{2}$, or for the recyclingof respiration-derived $\mathrm{CO}_{2}$ by symbiont photosynthesis. These can cause errors in calculation of gross carbon uptake rates. The growth rate method makes two assumptions: (1) rates of host- and symbiont respiration are equivalent in the light and in the dark; and (2) as $\mathrm{O}_{2}$ consumption reflects the combined respiratory activities of animal host and algal symbiont, the proportions of host- and symbiont respiration reflect their relative biomass (designated $B$ and 1- $B$, respectively) (Muscatine et al., 1981, 1983). Photorespiration and lightenhanced respiration in Symbiodinium (Burris, 1977; Tytler and Trench, 1986; Suggett et al., 2008; Schrameyer et al., 2014), and the stimulatory effect of irradiance on holobiont respiration (Edmunds and Davies, 1988; Harland and Davies, 1995; Anthony and Hoegh-Guldberg, 2003) call the first assumption into question, and testing assumption (2) has proven difficult. To date, estimates of algal symbiont respiration in hospite have generally relied on regression analyses of algal cell density as a predictor of holobiont respiration (Jacques et al., 1983; Hoegh-Guldberg and Smith, 1989; Hoogenboom et al., 2010), or on direct, in-vitro assessments of freshly isolated or cultured algal symbionts (Dustan, 1982; Muller-Parker, 1984; Fitt and Cook, 2001; Hoogenboom et al., 2010; Al-Sofyani and Floos, 2013). These approaches are not satisfactory, since the first assumes no effect of symbiont density on host respiration, and the second is likely confounded by the respiratory activities of residual host material and substantial physiological changes when Symbiodinium are removed from the host (see Goiran et al., 1996, 1997; Wang et al., 2011).

Aerobic respiration in eukaryotes occurs primarily in mitochondria; organelles that generate ATP through oxidative phosphorylation using tricarboxylic acid (TCA) cycle-derived NADH (Berg et al., 2002). In symbiotic cnidarians, the regulation of mitochondrial integrity and associated cell-signaling pathways is a component of their response to acute abiotic stressors such as elevated temperature (Dunn et al., 2012; Hawkins et al., 2013, 2014; Paxton et al., 2013; Lutz et al., 2015). Moreover, adjustments to mitochondrial function might be a general mechanism by which marine species acclimatize to a changing environment (Guderley and Johnston, 1996; Shama et al., 2014; Dixon et al., 2015). Given its importance to aerobic metabolism, it is surprising that mitochondrial activity has received relatively little attention as a useful marker of respiration in the cnidarian-Symbiodinium association. However, mitochondrial function, density, and integrity are commonly used markers of aerobic respiration in mammals (e.g., Srere, 1969; Wu et al., 1999; Spinazzi et al., 2011). For instance, analysis of mitochondrial genome copy number (relative to that of the nuclear genome) can be used to estimate mitochondrial density (Wu et al., 1999; Moraes, 2001; Miller et al., 2003; Ballard and Melvin, 2007; Urschel and O'Brien, 2008; Qiu et al., 2013). Additionally, the activity of mitochondrial electron transport complexes and of the TCA-cycle rate-limiting enzyme citrate synthase (abbreviated as CS hereafter) are useful correlates of respiratory activity in planktonic (Båmstedt, 1980; Clarke and Walsh, 1993; Thuesen and Childress, 1994; Torres et al., 1994; Kawall et al., 2001; Bellucci, 2004; De Wit et al., 2015) and benthic marine invertebrates (Marsh et al., 1999; Pace et al., 2006). Mitochondrial enzyme activity has been measured in corals and sea anemones (Sarkissian and Boatwright, 1975; Gattuso et al., 1993; Agostini et al., 2013; Henry and Torres, 2013; Rivest and Hofmann, 2014) but never, to our knowledge, with the specific aim of elucidating the partitioning of respiration between host and symbiont in an intact symbiosis. 
We sought to investigate variability in respiratory function in the cnidarian-dinoflagellate symbiosis using a natural population of the sea anemone Exaiptasia pallida (=Aiptasia pallida, Grajales and Rodriguez, 2014) alongside anemones re-infected with either natural (homologous) or introduced (heterologous) Symbiodinium species. Initially, we developed a quantitative PCR (QPCR) assay to determine host mitochondrial genome copy number cell $^{-1}$ (the ratio of host mitochondrial DNA [mtDNA] to nuclear DNA [nucDNA], henceforth referred to as "mtDNA/nucDNA"). We hypothesized that mtDNA/nucDNA is a significant predictor of protein-normalized mitochondrial citrate synthase enzyme activity and holobiont respiration rate, and thus reflects tissue mitochondrial density. Secondly, we hypothesized that activities of host- and symbiont mitochondrial citrate synthase enzyme are significant predictors of holobiont respiration rate. Due to the potential for inorganic nutrient- and carbon-limitation at high symbiont number (Cook et al., 1988; Weis, 1993), we predicted that Symbiodinium densities (per mg host protein) would correlate negatively with Symbiodinium specific CS activity. We also predicted that the inverse would be true for host specific CS activity, which might be expected to increase with symbiont density due to the increased availability of photosynthetically-fixed carbon (Agostini et al., 2013). Finally, to test assumption (2) of the CZAR calculation (Muscatine et al., 1981, 1983), we hypothesized that the partitioning of total holobiont CS activity between host and symbiont is approximately equal to their biomass ratio, and that this relationship holds across different host-symbiont combinations.

\section{MATERIALS AND METHODS}

\section{Anemone Husbandry, Symbiodinium Removal, and Re-infection}

Specimens of E. pallida were collected from Key Largo, FL, USA in August 2014 and donated by Dr. William Fitt. Anemones were maintained in 15-L tanks supplied with constantly running natural seawater (1-micron-filtered and UV-sterilized, $26^{\circ} \mathrm{C}, 1$ $\mathrm{L} \min ^{-1}$ flow rate). Irradiance $\left(100 \mu \mathrm{mol}\right.$ photons $\left.\mathrm{m}^{-2} \mathrm{~s}^{-1}\right)$ was provided on a $12 \mathrm{~h}: 12 \mathrm{~h}$ light:dark cycle (lights on at 06:00) provided by cool white LEDs (Cree XP-G2; LED Supply, Randolph, VT, USA). Aposymbiotic E. pallida were obtained by subjecting a subset of anemones $(n>200)$ to a menthol treatment (Wang et al., 2012; Matthews et al., 2015), with dark-incubation used instead of the photosynthetic inhibitor diuron. Aposymbiosis was confirmed by the complete absence of Symbiodinium using a fluorescence microscope [EVOS system, ThermoFisher (Life Technologies), Waltham, MA, USA; excitation: $628 \pm 20 \mathrm{~nm}$, emission: $692 \pm 20 \mathrm{~nm}$ ]. Aposymbiotic animals were maintained in a $30-\mathrm{L}$ aquarium in the dark, and checked monthly for the presence of algal symbionts.

Novel E. pallida-Symbiodinium associations were established by exposing aposymbiotic anemones to one of two different Symbiodinium species $\left(\sim 1000\right.$ cells $\mathrm{mL}^{-1}$ in $500 \mathrm{~mL}$ seawater $)$ according to the methods of Hoadley et al. (2015). One group ( $n>30$ animals) was incubated with a homologous, monoclonal Symbiodinium culture established from Symbiodinium originally isolated from the same E. pallida population and maintained in semi-continuous growth in f/2-Si culture media (Guillard, 1973) for period of at least 1 year. Another set of anemones $(n>30)$ was exposed to a heterologous culture of Symbiodinium minutum (ID: Pk702) originally isolated from the octocoral Plexaura kuna. Symbiodinium were genetically identified by amplifying and sequencing the internal transcribed spacer-2 (ITS2) region of nuclear ribosomal DNA (LaJeunesse, 2002). In addition, culture Pk702 was confirmed as S. minutum through the PCRamplification and sequencing of the B7Sym 15 microsatellite locus (Pettay and LaJeunesse, 2007).

Algae were noted as ITS2-types A4 and B1 for the homologous symbiont and $S$. minutum isolates, respectively. Newly symbiotic animals were maintained in separate flow-through tanks for at least 3 months before any physiological analysis was undertaken. A third group of aposymbiotic anemones $(n=24)$ were placed under lights for 8 weeks without being exposed to any Symbiodinium cells. These anemones remained aposymbiotic (as confirmed by fluorescence microscopy). To confirm symbiont genetic identity in re-infected animals, Symbiodinium DNA was extracted from 5 to 10 anemones per group, and the ITS2 region was amplified as described by LaJeunesse (2002). In all instances, anemones contained the appropriate ITS2-type. Animals were fed weekly with freshly hatched Artemia nauplii and, to reduce the effect of trophic status on physiological variables, sampling was conducted 3 days prior to feeding. Further, all sampling occurred between 09:00 and 15:00 to lessen the influence of diel periodicity in metabolic activity (Akimoto et al., 2005; Hoadley et al., 2011; Sorek et al., 2013).

\section{Measurements of Respiration and Photosynthesis as In-vivo Oxygen Flux}

Respiration and photosynthesis of individual anemones [oral disk diameter $>4 \mathrm{~mm}$ for natural E. pallida $(n=53)$, 4-6 mm for re-infected animals $(n=19$ per Symbiodinium species)] was measured in sealed glass scintillation vials fitted with an internal stir bar and an oxygen sensitive optode (Fibox 4, PreSens Gmbh, Regensburg, Germany). Vials were immersed in a constant $26^{\circ} \mathrm{C}$ water bath and maintained in darkness for $15 \mathrm{~min}$, during which time anemones relaxed and expanded their tentacles. Illumination was provided for $20 \mathrm{~min}$ at an irradiance of $200 \mu \mathrm{mol}$ photons $\mathrm{m}^{-2} \mathrm{~s}^{-1}$ (slightly below saturating irradiance, and provided by the same LEDs described above), after which, the LEDs were turned off for a final 30-min period to allow measurement of steady-state dark respiration. Background $\mathrm{O}_{2}$ flux was determined using vials containing $1-\mu \mathrm{m}$-filtered, UV-sterilized seawater, and was found to be negligible. After respirometry assays, each anemone was transferred to a 2-mL screw-cap vial, snap-frozen in liquid nitrogen, and stored at $-80^{\circ} \mathrm{C}$. The volume of seawater in the chamber was measured, and rates of holobiont dark respiration were calculated as moles $\mathrm{O}_{2}$ consumed hour ${ }^{-1}$. Dark respiration rates were then subtracted from net photosynthetic rates (moles $\mathrm{O}_{2}$ produced hour ${ }^{-1}$ during the light-phase) to generate values for gross photosynthesis. Respiration- and gross photosynthesis rates were normalized to soluble animal protein and symbiont cell number, respectively (described below). 


\section{Anemone Processing and Symbiodinium Density Analysis}

Unless otherwise indicated, reagents were obtained from Fisher Scientific (Pittsburgh, PA, USA) and all steps were carried out at $4{ }^{\circ} \mathrm{C}$ or on ice. Anemones were thawed in their $2-\mathrm{mL}$ screw cap vials and $0.6-1 \mathrm{~mL}$ ice-cold lysis buffer $(25 \mathrm{mM}$ Tris, $\mathrm{pH}$ 7.8, $1 \mathrm{mM}$ EDTA, $10 \%$ glycerol [v/v]) was added to each vial. Anemones were then homogenized in a chilled bead-beater (FastPrep ${ }^{\circledR}-24$, MP Bio, Santa Ana, CA, USA) for $60 \mathrm{~s}$ at a speed of $6 \mathrm{~m} \mathrm{~s}^{-1}$ with a 5 -mm-diameter stainless steel bead. The homogenate was inspected visually $(100 \times$ magnification $)$ to confirm anemone tissue disruption and Symbiodinium cell integrity. A $100-\mu \mathrm{L}$ sample was removed, fixed with $5 \mu \mathrm{L}$ glutaraldehyde $(8 \%[\mathrm{w} / \mathrm{v}]$ stock solution in water), and stored at $4^{\circ} \mathrm{C}$ in the dark for later quantification of Symbiodinium cell densities. The remaining homogenate was centrifuged at $3000 \times \mathrm{g}$ for $30 \mathrm{~s}$. Two hundred microliters of the supernatant were removed for animal DNA extraction (see below) and the pellet was re-suspended. The sample was then centrifuged for $5 \mathrm{~min}$ at $700 \times \mathrm{g}$ to separate the Symbiodinium cells from the remaining anemone material. The Symbiodinium pellet was immediately snap-frozen in liquid nitrogen and transferred to a $-80^{\circ} \mathrm{C}$ freezer. The supernatant ("anemone fraction") was centrifuged at high speed $(16,100 \times \mathrm{g}, 20 \mathrm{~min})$ to remove particulates, and aliquots of the clear supernatant were snapfrozen and stored at $-80^{\circ} \mathrm{C}$.

In order to remove residual animal protein, Symbiodinium pellets were thawed, re-suspended in $1 \mathrm{~mL}$ ice-cold wash buffer (as lysis buffer above, but with the addition of $0.01 \%$ [v/v] Triton $\mathrm{X}-100$ ), and centrifuged for $5 \mathrm{~min}$ at $700 \times \mathrm{g}$. The supernatant was discarded and the pellet re-suspended in fresh ice-cold wash buffer. This procedure was repeated four times, after which the supernatant was clear and the pellet dark brown, with little evidence of contaminating anemone material. Symbiodinium cells were finally re-suspended in $300 \mu \mathrm{L}$ ice-cold lysis buffer in a clean $1.5-\mathrm{mL}$ tube containing a $200-\mu \mathrm{L}$-volume of 0.5 $\mathrm{mm}$-diameter acid-washed glass beads. Cells were lysed in a chilled bead-beater (see above) for $3 \mathrm{~min}$ at a speed of $6.5 \mathrm{~m}$ $\mathrm{s}^{-1}$. The lysate was inspected visually $(100 \times$ magnification $)$, before centrifugation to remove particulates (16,100 × g, $20 \mathrm{~min})$. Aliquots of the supernatant were then snap-frozen in liquid nitrogen and stored at $-80^{\circ} \mathrm{C}$.

Total soluble anemone and Symbiodinium protein were determined using a linearized Bradford assay (Ernst and Zor, 2010). To test the effectiveness of the algal washing steps described above, a standard curve was constructed by spiking 12 Symbiodinium pellets from similar-sized anemones (in triplicate) with 24-1200 $\mu \mathrm{g}$ anemone protein "contamination" originating from crude homogenates that had been gently centrifuged $(500 \times$ $\mathrm{g}$ for $5 \mathrm{~min}$ ) to remove algal cells. Algal pellets were then washed and a $50-\mu \mathrm{L}$ sample was removed and fixed for cell counts. The remaining cells were lysed as described above. Symbiodinium protein content was then measured for each pellet, normalized to cell number (see below), and plotted against the respective amount of anemone material added.

Symbiodinium densities were quantified using an Improved Neubauer hemocytometer and a fluorescence microscope to visualize cells' chlorophyll $a$ fluorescence (see above). Field of view was determined using the EVOS operating software $(4 \times$ objective), and cells were counted using the "Analyze Particles" tool in Image (NIH, Bethesda, MD, USA). At least 6 independent images were analyzed for each sample, and cell numbers were normalized to anemone protein content.

\section{Biochemical Analysis of Mitochondrial Function}

Anemone and Symbiodinium aerobic capacity was quantified as the activity of the TCA cycle rate-limiting enzyme citrate synthase (CS), measured according the methods of Srere (1969) modified for use with small marine invertebrates. All samples were analyzed within 1 month of freezing. Representative results of assay optimization and validation procedures are provided in ESM Figure S1. Briefly, $20 \mu \mathrm{L}$ of thawed anemone or Symbiodinium supernatant (diluted to yield 2-6 $\mu \mathrm{g}$ of protein) was added in triplicate to wells in a 96-well plate (Greiner BioOne, Monroe, NC, USA) alongside triplicate blanks (20 $\mu \mathrm{L}$ lysis buffer) and positive controls $\left[20 \mu \mathrm{L}\right.$ citrate synthase $\left(1 \mathrm{U} \mathrm{mL}^{-1}\right.$ in lysis buffer; Sigma-Aldrich, St. Louis, MO, USA)]. One hundred and seventy microliters of assay buffer (111 mM Tris, $\mathrm{pH} 7.8$, $0.11 \%[\mathrm{v} / \mathrm{v}]$ Triton X-100) containing $294 \mu \mathrm{M} 5,5^{\prime}$-dithiobis(2-nitrobenzoic acid) (DTNB; Sigma-Aldrich, see above) and $588 \mu \mathrm{M}$ acetyl-coenzyme A (Sigma-Aldrich, see above) were then added to all wells. DTNB stock solutions $(5 \mathrm{mM})$ were made fresh in $0.1 \mathrm{mM}$ Tris buffer, $\mathrm{pH}$ 8.0. Acetyl-coenzyme A solutions were prepared at a concentration of $12.35 \mathrm{mM}$ in distilled water, stored in aliquots at $-80^{\circ} \mathrm{C}$, and used within 6 months.

To control for non-CS-specific reaction products following the addition of assay buffer, baseline absorbance $(\lambda=412 \mathrm{~nm})$ was recorded for $3 \mathrm{~min}$ using a microplate reader (Fluostar Omega, BMG, Cary, NC, USA) maintained at a temperature of $26^{\circ} \mathrm{C}$. The CS-catalyzed reaction was initiated by adding $10 \mu \mathrm{L}$ oxaloacetate to each well (OA; Sigma-Aldrich, see above; $12 \mathrm{mM}$ stock solution prepared fresh in distilled water and stored on ice), giving a final concentration of $600 \mu \mathrm{M}$ OA. Sample absorbance was monitored at $412 \mathrm{~nm}$ for a further $3 \mathrm{~min}$, and CS enzyme activity was derived using the following equation:

$$
\begin{aligned}
& \text { CS Specific Activity }\left(U \mathrm{mg}^{-1}\right) \\
& =\frac{\left(\triangle 412_{O A}-\triangle 412_{\text {blank }}\right) \times V_{\text {reaction }} \times D}{13.6 \times L \times V_{\text {sample }} \times P}
\end{aligned}
$$

Where $\Delta 412$ is the linear rate of change in 412-nm absorbance prior to and after the addition of $\mathrm{OA}, \mathrm{V}$ is the volume $(\mathrm{mL}), \mathrm{D}$ is the sample dilution factor, $13.6\left(\mathrm{mM}^{-1} \mathrm{~cm}^{-1}\right)$ is the $412-\mathrm{nm}$ extinction coefficient for the reaction product, $\mathrm{L}$ is the optical path-length $(\mathrm{cm})$ and $\mathrm{P}$ is the sample protein concentration $\left(\mathrm{mg} \mathrm{mL}^{-1}\right)$. Total Symbiodinium and animal CS activities were calculated as the product of the respective specific activity and total protein contents.

\section{Quantification of Anemone Mitochondrial Copy Number}

A plasmid-cloning and quantitative-PCR approach was used to determine mtDNA/nucDNA in the natural E. pallida population. 
Since DNA extraction method can influence the apparent mtDNA/nucDNA ratio (Andreu et al., 2009; Guo et al., 2009), anemone genomic DNA was extracted using two independent methods. For some animals $(n=33)$, DNA was extracted using a Wizard $^{\circledR}$ Genomic DNA Extraction kit (Promega Corporation, Madison, WI, USA). Briefly, the 200- $\mu \mathrm{L}$ host homogenate was initially mixed with $400 \mu \mathrm{L}$ Wizard ${ }^{\circledR}$ nuclei lysis buffer. Samples were incubated with $0.1 \mathrm{mg} \mathrm{mL}^{-1}$ proteinase $\mathrm{K}$ for $2 \mathrm{~h}$ at $60^{\circ} \mathrm{C}$ (vortexed every $20 \mathrm{~min}$ ). Proteins were removed by precipitation with $360 \mu \mathrm{L} 9 \mathrm{M}$ ammonium acetate, 20-min incubation at $4^{\circ} \mathrm{C}$ and centrifugation at $15,000 \times \mathrm{g}$ for $5 \mathrm{~min}$. Six hundred microliters of supernatant were aspirated and transferred to a clean tube containing $700 \mu \mathrm{L}$ isopropanol and $25 \mu \mathrm{L} 3 \mathrm{M}$ sodium acetate. DNA was left to precipitate on ice for $20 \mathrm{~min}$ before centrifuging $(15,000 \times \mathrm{g}$ for $5 \mathrm{~min})$. The DNA pellet was washed with ethanol, air-dried under sterile conditions at $30^{\circ} \mathrm{C}$, and finally dissolved in $50 \mu \mathrm{L}$ nucleasefree water (BioExpress, Kaysville, UT, USA). DNA from a second group $(n=20)$ was extracted and purified using a QiaAmp DNA Mini kit (Qiagen, Germantown, MD, USA), with the $200-\mu \mathrm{L}$ aliquot of animal homogenate initially mixed with $200 \mu \mathrm{L}$ "Buffer AL" and $20 \mu \mathrm{L}$ Qiagen Proteinase K. DNA was purified following the manufacturer's instructionsalbeit with an additional column-wash with "Buffer AW2"and eluted in $50 \mu \mathrm{L}$ "Buffer AE." DNA concentration was measured using a Quant-iT PicoGreen ${ }^{\circledR}$ assay (ThermoFisher [Invitrogen], Waltham, MA, USA) and purity was determined spectrophotometrically as the $260 / 230 \mathrm{~nm}$ and $260 / 280 \mathrm{~nm}$ absorbance ratios (NanoDrop ${ }^{\circledR}$, ThermoFisher, Waltham, MA, USA). The $260 / 280 \mathrm{~nm}$ ratio was consistently $>1.8$, but the $260 / 230 \mathrm{~nm}$ ratio was variable, particularly in samples purified using the Wizard ${ }^{\circledR}$ Promega kit (range $=1.4-2.2$ ), however, this had a negligible effect on the efficiency of subsequent QPCR reactions (see ESM, Figure S2A).

\section{Primer Design and Standard Curve Construction}

Oligonucleotide primers (Table 1) were designed using webbased software (PrimerQuest ${ }^{\circledR}$, Integrated DNA Technologies Inc., Coralville, IA, USA) for two mitochondrial DNA sequences and one nuclear DNA sequence. Mitochondrial sequences were: (1) $101 \mathrm{bp}$ of the cytochrome $c$ oxidase subunit 1 gene (CO1); and (2) 144 bp of the ATP-sythase subunit 6 gene (ATP6). The nuclear DNA sequence was 89 bp of the nuclear gene eukaryotic translation elongation factor 1alpha $(E F-1-\alpha)$, which is present as a single copy in $E$. pallida (Baumgarten et al., 2015). Template sequences for mitochondrial targets were obtained from the mitochondrial genome of Aiptasia pulchella [CO1: nucleotides 15,388-17,860 in GenBank Acc. No: NC_022265, (http://www.ncbi.nlm.nih.gov/ gene/16792268); ATP6: nucleotides 19086-19775 in NC_022265, (http://www.ncbi.nlm.nih.gov/gene/16792265)]. E. pallida EF-1$\alpha$ was identified by BLAST-aligning an EF-1- $\alpha$ sequence from the Nematostella vectensis genome (Putnam et al., 2007) against an $A$. pallida expressed sequence tag library (AiptasiaBase; Sunagawa et al., 2009). BLASTX analysis of the best hit (AiptasiaBase “contig 642," $E=0$ ) against the A. pallida genome (Baumgarten et al., 2015; http://aiptasia.reefgenomics.org/) strongly matched an EF-1- $\alpha$ protein $(E=0$; Gene ID: gnl|BL_ORD_ID $\mid 13307$, AIPGENE865 sp|P29520).

Primer validation was undertaken using end-point PCR, with each reaction containing $20 \mathrm{ng}$ anemone DNA in a $20-\mu \mathrm{L}$ mix of $1 \times$ Standard Mg-free PCR buffer, $0.25 \mathrm{U}$ Taq DNA polymerase, $0.25 \mu \mathrm{M}$ (CO1 and ATP6) or $0.5 \mu \mathrm{M}$ primers $(E F$ $1-\alpha$ ), $2.5 \mathrm{mM} \mathrm{MgCl} 2$, and $0.25 \mathrm{mM}$ dNTPs (reagents from New England Biolabs, Ipswich, MA, USA; primers from Integrated DNA Technologies, see above). Cycling conditions were $94^{\circ} \mathrm{C}$ for $2 \mathrm{~min}$, followed by thirty cycles of $94^{\circ} \mathrm{C}$ for $15 \mathrm{~s}, 60^{\circ} \mathrm{C}$ for $30 \mathrm{~s}$, and $72^{\circ} \mathrm{C}$ for $30 \mathrm{~s}$, with a final elongation at $72^{\circ} \mathrm{C}$ for $10 \mathrm{~min}$. Agarose gel electrophoresis confirmed a single PCR product for each primer set and, after product purification (ExoSAP-IT, Affymetrix, Santa Clara, CA, USA), amplicons were sequenced in both directions using the respective PCR primers (GeneWiz, South Plainfield, NJ, USA). Electropherograms were inspected visually to confirm the reliability of base-calling and sequences were compared to NCBI Genbank or Aiptasia genome databases. In all cases the sequences aligned most strongly with those used for primer design.

Additionally, a longer sequence of each of the three target genes (>300-bp, encompassing the respective QPCR target) was PCR-amplified (primers as in Table 1, PCR conditions as above) and cloned into bacterial plasmids using a TOPO TA Cloning ${ }^{\circledR}$ kit (Life Technologies, see above). Plasmids were then transformed into One Shot ${ }^{\circledR}$ Mach $1^{T M}$ T1 phage-resistant chemically competent Escherichia coli (Life Technologies, see above). After $24 \mathrm{~h}$ bacterial growth in Luria-Bertani media at $37^{\circ} \mathrm{C}$, plasmids were extracted and purified using a PureLink ${ }^{\circledR}$ Plasmid MiniPrep kit (Invitrogen, see above). Inserts were sequenced in both directions using M13R and M13(-21)F primers (Genewiz, South Plainfield, NJ, USA) to confirm the presence and correct orientation of the respective inserts. Plasmid DNA was then linearized with EcoR1 restriction endonuclease (Invitrogen, see above; ESM Figure S3) and quantified using a PicoGreen ${ }^{\circledR}$ assay. Linearized plasmids (encoding the respective QPCR target sequences) were used to construct a seven-level $\log _{10}$-dilution standard curve $\left(10^{7}-10^{1}\right.$ copies per reaction, in triplicate) prior to each set of QPCR reactions. Sequences for QPCR amplicons and longer TOPO TA-cloned fragments are provided in the accompanying ESM.

\section{QPCR Analysis}

Duplicate $2-\mu \mathrm{L}$ aliquots of extracted DNA (5-10 ng $\left.\mu \mathrm{L}^{-1}\right)$ were added to a $18-\mu \mathrm{L}$ reaction mix (SensiMix ${ }^{\mathrm{TM}}$ SYBR Hi-ROX; Bioline, Taunton, MA, USA) such that the final mix contained $0.25 \mu \mathrm{M}$ CO1 or ATP6 primers, or $0.5 \mu \mathrm{M} E F-1$ - $\alpha$ primer. Genefragments were amplified using an AB-7500 real-time QPCR system [ThermoFisher (Applied Biosystems), Waltham, MA, USA], with the following cycling conditions: $94^{\circ} \mathrm{C}$ for $10 \mathrm{~min}$, followed by 40 cycles of $94^{\circ} \mathrm{C}$ for $15 \mathrm{~s}, 60^{\circ} \mathrm{C}$ for $1 \mathrm{~min}$, and $72^{\circ} \mathrm{C}$ for $15 \mathrm{~s}$. A melt-curve analysis $\left(60-94^{\circ} \mathrm{C}\right.$ in $0.3^{\circ} \mathrm{C}$ increments, $30 \mathrm{~s}$ per step) was carried out in order to detect non-specific amplification products. A single PCR product was detected in all cases, with a melting temperature within $1^{\circ} \mathrm{C}$ of the theoretical melting temperature of the sequenced amplicon as determined by a web-based tool (OligoCalc; Kibbe, 2007). Baseline values 
TABLE 1 | Primers used for the amplification of mitochondrial- and nuclear target genes in order to quantify host mitochondrial genome copy number (mtDNA/nucDNA ratio) in Exaiptasia pallida.

\begin{tabular}{|c|c|c|c|c|}
\hline Objective & Target & Size (bp) & Forward Primer $\left(5^{\prime}-3^{\prime}\right)$ & Reverse Primer $\left(3^{\prime}-5^{\prime}\right)$ \\
\hline \multirow[t]{3}{*}{ TOPO ${ }^{\circledR}$ Cloning (standard curve) } & $\mathrm{COl}$ & 356 & AGC CGT CAG AGA CAG TAA & CGT GAC CAA GCC CTA ATA AA \\
\hline & ATP6 & 342 & GGT TGT TAC GTT AGG CTT GT & ACT TGA ATA ACC GCC ACT \\
\hline & $E F-1-\alpha$ & 803 & TTC TCT CTT ACA CCC TTG G & CTT GTC AGT GGG TCT CTT \\
\hline \multirow[t]{3}{*}{ QPCR } & $\mathrm{COI}$ & 101 & GTC TCC CAG CCG GAA ATA AA & ACC ATT GTC AGC ATC TCT CG \\
\hline & ATP6 & 144 & CGT CTC GCC GCA AAT TTA TC & TGC GGC CTC TAG TAG ACT TA \\
\hline & $E F-1-\alpha$ & 89 & AGC ACT GAG CCA CCA TAC AG & TTG GGT TAT AGC CGG TCT TC \\
\hline
\end{tabular}

CO1, Cytochrome c oxidase subunit 1; ATP6, ATP synthase subunit 6; EF-1- $\alpha$, Eukaryotic translation elongation factor 1-alpha. Annealing temperature was 60 $\mathrm{C}$ for all primer sets. Specific details of PCR conditions are provided in the accompanying Electronic Supplementary Information.

were determined automatically and threshold value was set manually at 0.04 (maintained across all samples and standards). Amplification efficiencies were $93-96 \%$ in all instances. The number of CO1, ATP6, and EF-1- $\alpha$ sequences per $20-\mu \mathrm{L}$ reaction was determined by comparing mean $C_{t}$ values for each sample to the respective log-dilution standard curve, and CO1/EF-1- $\alpha$ and ATP6/EF-1- $\alpha$ ratios were then calculated.

\section{Statistical Analysis}

Total anemone- and Symbiodinium protein contents were used to define the parameters $\beta$ and $1-\beta$, respectively (Muscatine et al., 1981), with the latter representing the proportion of Symbiodinium biomass relative to that of the holobiont ("symbiont biomass fraction"). Likewise, the algal contribution to holobiont CS activity was calculated (designated as the "symbiont respiration fraction," abbreviated as $\mathrm{R}_{\text {Sym }}$ ). Predictive associations between symbiont density, host-, symbiont-, and total holobiont citrate synthase activity, host mtDNA/nucDNA ratio and total biomass, holobiont respiration, 1-ßand $\mathrm{R}_{\text {Sym }}$ were investigated using linear regression models [" $\operatorname{lm}()$ " function] in R v. 3.2.1 (R Development Core Team, 2015). Standardized residual plots were examined visually and residuals were tested for homoscedasticity and normality. Distributions and variances of standardized residuals were, in a few cases, not normal or homogeneous. Therefore, all regression analyses were bootstrapped to improve robustness and to provide estimates of $95 \%$ confidence intervals for regression parameters ["boot()" function; $n=2000$ replications]. Where a multiple regression analysis was performed, co-linearity between predictors was examined using the "vif()" function in R package "car." Associations where a predictor was not hypothesized a priori were analyzed using Pearson's correlation test. Comparisons between anemones re-infected with homologous ITS2-type A4 Symbiodinium or heterologous S. minutum were conducted using Student's $t$-tests. Additionally, differences in the relationship between 1- $\beta$ and $R_{\text {Sym }}$ in the different holobionts were tested for using a multiple regression, with $1-\beta$ and "holobiont" as independent predictors of $\mathrm{R}_{\mathrm{Sym}}$. Assumptions of normality and homoscedasticity were assessed using Shapiro-Wilk- and Levene's tests, respectively. Non-normal or heteroscedastic data were $\log _{10}$-transformed prior to analysis with $t$-tests. Data that could not be adequately transformed were analyzed using nonparametric Wilcoxon Rank-Sum tests.

\section{RESULTS}

\section{Validation of Biochemical and Molecular Techniques}

Total anemone citrate synthase (CS) activity was a significant predictor of holobiont respiration rate, explaining $82 \%$ of observed variance (Figure 1A, Table 2). In-hospite Symbiodinium CS activity was also a significant predictor of holobiont respiration (Table 2), although it explained less variation than did host CS $\left(R^{2}=0.70 v s . R^{2}=0.82\right)$. The explained variance in holobiont respiration increased to $88 \%$ when total host and symbiont CS activities were combined (Figure 1B, Table 2).

For the Symbiodinium CS samples artificially "spiked" with animal homogenates, the apparent protein content per Symbiodinium cell did not change significantly [Linear Regression; Predictor: amount of anemone protein added to sample, Dependent: Symbiodinium protein content per cell, $F_{(1,11)}=0.49, p>0.5$, ESM Figure S2B]. Furthermore, there was no positive correlation between anemone and Symbiodinium specific CS activities (permg protein), which would have been expected if CS-rich anemone material was contaminating the algal samples. Rather, a statistically significant negative correlation was apparent (Figure 1C; Pearson's correlation test: $r=-0.455, t=-3.538, \mathrm{df}=48, p=0.0009)$.

In addition to analysis of CS activity, we tested whether the animal mitochondrial/nuclear genome ratio might be a useful indicator of mitochondrial density in E. pallida. The DNA extraction method had no effect on the mtDNA/nucDNA ratio (ESM Figure S2C). Therefore, data were pooled for subsequent analyses. Anemone mtDNA/nucDNA was highly variable (range $=20-300$ ) and was not a significant predictor either of protein-normalized whole-organism respiration rate or anemone specific CS activity (Figures 2A,B). The very strong correlation between CO1/EF-1- $a$ and ATP6/EF-1- $a$ ratios $\left(R^{2}>\right.$ 0.95; Figure 2C) meant that this was the case regardless of which mitochondrial gene was used as the mtDNA target.

\section{Variability in Respiratory Function in E. pallida}

In naturally symbiotic E. pallida, holobiont respiration rate (mg host protein ${ }^{-1}$ ) and host CS specific activity were both 

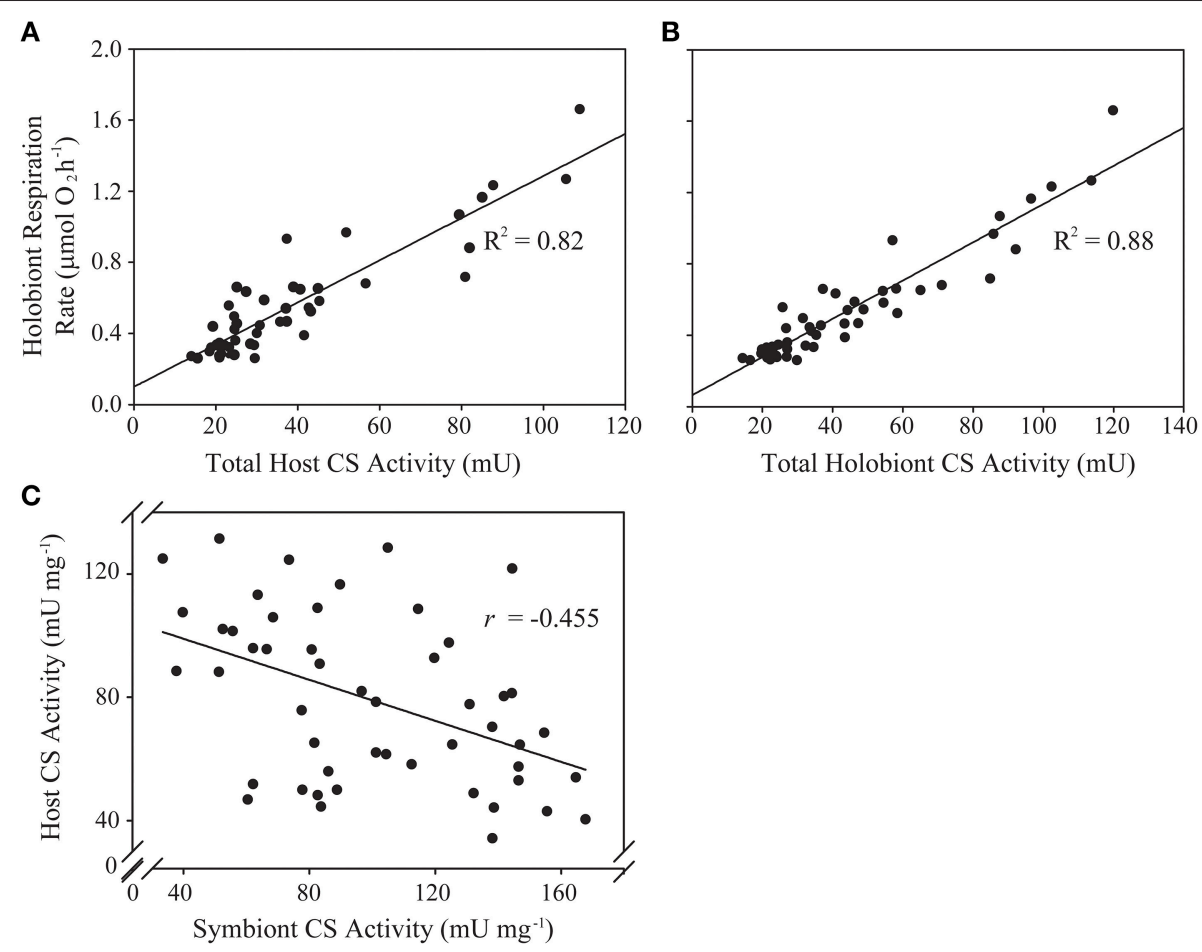

FIGURE 1 | Predictive and correlative associations between animal host- and algal symbiont citrate synthase (CS) activity and holobiont respiration rate in a natural population of Exaiptasia pallida. (A) Linear regression analysis of total host CS activity $(U)$ as a predictor of holobiont respiration rate $\left(\mu\right.$ mol $\mathrm{O}_{2}$ $\left.\mathrm{h}^{-1}\right)$; (B) Linear regression analysis of total holobiont CS activity (host + symbiont; $\mathrm{U}$ ) as a predictor of holobiont respiration rate $\left(\mu \mathrm{mol} \mathrm{O}_{2} \mathrm{~h}^{-1}\right)$; (C) Pearson's correlation analysis of the relationship between host- and symbiont specific CS activities $\left(\mathrm{U} \mathrm{mg}^{-1}\right)$. All relationships are statistically significant at $p<0.001$.

TABLE 2 | Results of bootstrapped linear regression analysis ( $n=2000$ replications) of anemone host, algal symbiont-, and total holobiont citrate synthase (CS) activity (U) in Exaiptasia pallida as predictors of total holobiont respiration rates $\left(\mu \mathrm{mol} \mathrm{O}_{2} \mathrm{~h}^{-1}\right)$.

\begin{tabular}{|c|c|c|c|c|c|}
\hline Predictor & Value (95\% Cl) & $t$ & $p(t)$ & $F(\mathrm{df})$ & $p(F)$ \\
\hline Total host CS activity & $11.867(9.50,13.84)$ & 14.849 & $<0.0001$ & $220.484(1,48)$ & $<0.0001$ \\
\hline Intercept & $0.100(0.033,0.173)$ & 2.818 & 0.007 & & \\
\hline Total symbiont CS activity & $21.947(18.34,28.88)$ & 9.032 & $<0.0001$ & $81.570(1,48)$ & $<0.0001$ \\
\hline Intercept & $0.306(0.264,0.362)$ & 11.239 & $<0.0001$ & & \\
\hline Total holobiont CS activity & $10.715(9.27,12.43)$ & 19.089 & $<0.0001$ & $364.383(1,48)$ & $<0.0001$ \\
\hline Intercept & $0.064(-0.004,0.118)$ & 2.162 & 0.036 & & \\
\hline
\end{tabular}

Bold values indicate statistical significance at $p<0.05$.

positively associated with algal symbiont density (Figures 3A,B, Table 3). However, we also observed a negative log-linear relationship between host specific CS activity and anemone biomass (total animal DNA content; Figure 3C). Therefore, a multiple regression model was applied in order to parse the effects of these two covariates. Symbiont density alone explained $55.4 \%$ of variance in natural log-transformed host CS activity (see Table 3 for regression analysis parameters). Including total animal DNA (natural log-transformed) as a predictor increased the explained variance to $73.6 \%\left[t_{\text {biomass }}=-5.653, p<0.0001\right.$; Full model: $\left.F_{(2,46)}=67.79, p<0.0001\right]$. Alone, total animal DNA explained $38.5 \%$ of variation in host specific CS activity [ $t_{\text {biomass }}=-5.574, p<0.0001$; Full model: $F_{(1,47)}=31.07$, $p<0.0001$ ]. A weak negative association (statistically significant only for the y-intercept) was noted between symbiont CS specific activity and algal symbiont density (Figure 3D, Table 3).

Analysis of CS enzyme activity as an indicator of aerobic capacity allowed us to estimate the partitioning of respiratory activity between host and symbiont and relate this to symbiont biomass. The symbiont biomass fraction (1- $B$; as defined by Muscatine et al., 1981) ranged from 0.03 to 0.21 in our natural E. pallida population, with a median value of 0.09 ( $n=$ 53). These data are plotted against the symbiont-respiration fraction $\left(\mathrm{R}_{\text {Sym }}\right)$ in Figure $4 \mathrm{~A}$, alongside a line with slope $=$ 1 describing equality between $1-\beta$ and $R_{S y m}$. Concretely, any point above (or below) this line represents a holobiont with a higher (or lower) $\mathrm{R}_{\text {Sym }}$ than would be expected from the value of $1-\beta$. The slope of the fitted regression line was significantly 


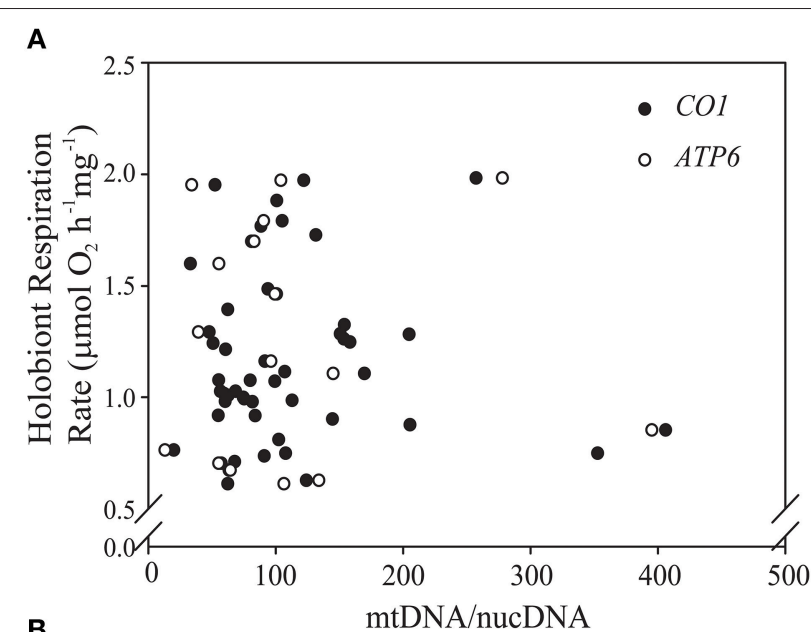

B
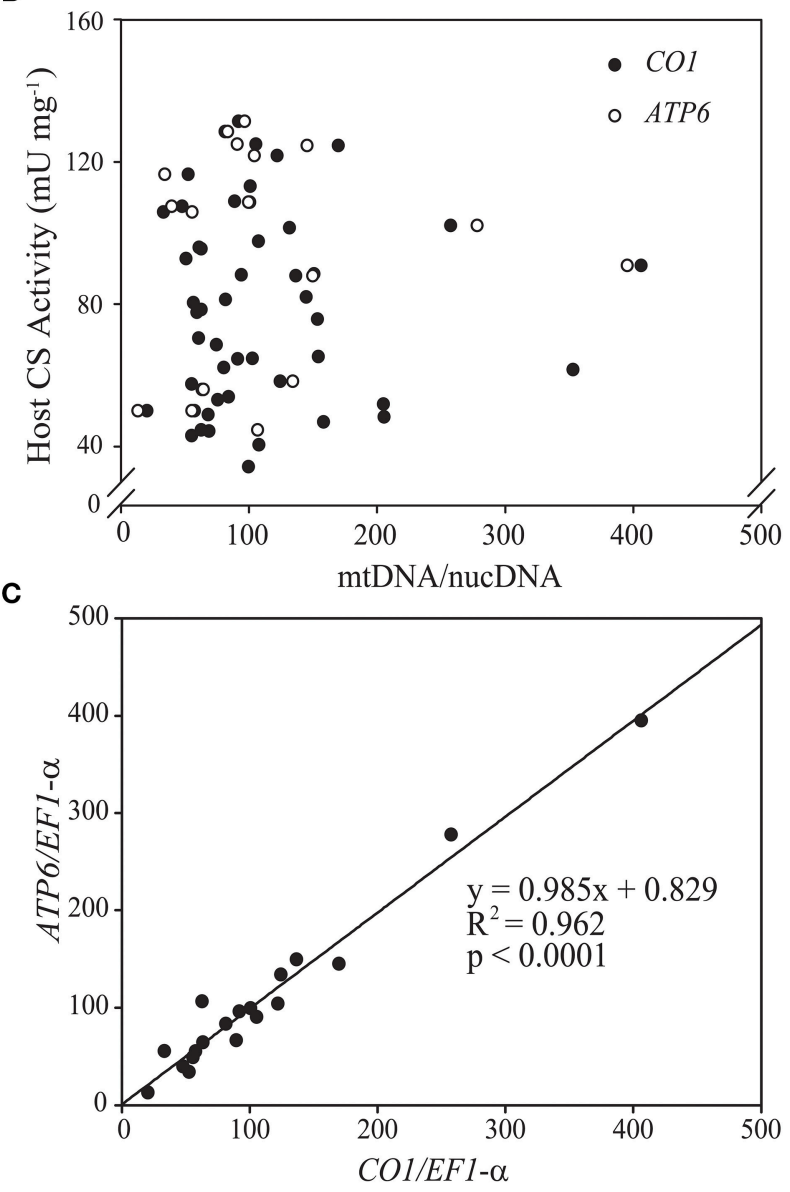

FIGURE 2 | Scatterplots of the relationships in Exaiptasia pallida between mitochondrial genome copy number (mtDNA/nucDNA ratio) and (A) holobiont respiration rate normalized to host protein content $\left(\mu \mathrm{mol} \mathrm{O} \mathrm{mg}^{-1} \mathrm{~h}^{-1}\right)$ and (B) host citrate synthase (CS) specific activity $\left(\mathbf{U} \mathbf{~ m g}^{-1}\right)$. Closed symbols represent values obtained using the mitochondrial cytochrome $c$ oxidase subunit 1 (CO1) gene, while open symbols represent values obtained using the mitochondrial ATP-synthase subunit 6 (ATP6) gene. Copy numbers for both genes were normalized to that of eukaryotic translation elongation factor 1 alpha $(E F-1-\alpha)$, a single-copy nuclear gene in $E$. pallida. Neither of the relationships in $(\mathbf{A}, \mathbf{B})$ was statistically significant at $p<0.05$. (C) Strong positive association between mtDNA/nucDNA as calculated using $\mathrm{CO} 1$ and ATP6 copy numbers normalized to EF-1- $\alpha$. different from unity $\left[F_{(1,49)}=38.03, p<0.0001\right.$; Slope $=$ $\left.0.689_{[(95 \% C I: 0.475,0.900), t=6.167, p<0.0001]}\right]$, which suggests that $\mathrm{R}_{\text {sym }}$ and $1-\beta$ are not equivalent in our naturally symbiotic $E$. pallida anemones.

In anemones separately re-infected with homologous and heterologous Symbiodinium species, we noted significant differences in symbiont density and holobiont respiration, both of which were higher in animals hosting the homologous Symbiodinium A4 (Figures 5A,B). S. minutum displayed a higher rate of photosynthetic activity per cell than did Symbiodinium A4 (Figure 5C), and this pattern was repeated in its CS specific activity, which was significantly elevated relative to that of Symbiodinium A4 (Figure 5D). Host CS specific activity did not differ between the two groups (Figure 5D), and no significant difference was observed in $\mathrm{R}_{\text {Sym }}$ (Figure $5 \mathbf{E}$, Table 4), despite there being a trend for higher $\mathrm{R}_{\text {Sym }}$ in the $E$. pallida-S. minutum holobiont. There was, however, a significant negative correlation between host- and symbiont specific CS activities in this particular symbiosis (Pearson's correlation test: $r=-0.708, t=-4.139$, df $=17, p=0.0006)$. Median values for 1- $ß$ for anemones hosting Symbiodinium A4 and S. minutum were similar at 0.08-0.09 (ranges: $0.02-0.16$ and 0.04-0.14, respectively). However, the relationship between $1-\beta$ and $R_{S y m}$ differed between holobionts, with the slope close to unity for E. pallida-S. minutum symbioses, but significantly lower for the E. pallida-Symbiodinium A4 holobiont [Figure 4B; Linear regression: $F_{(3,34)}=18.04, p<0.001 ; t_{(1-\beta \times \text { holobiont })}=3.404$, $p=0.002]$. These differences were mirrored in the $\mathrm{R}_{\text {Sym }} / 1-\beta$ ratios of individual anemones, which were significantly higher in animals hosting S. minutum (Table 4, Figure 5F).

\section{DISCUSSION}

It remains unclear how the metabolic activities of the animal host and its algal symbionts interact to determine the physiology of the symbiotic cnidarian "holobiont" (Yellowlees et al., 2008; Davy et al., 2012). Specifically, we have a limited understanding of the partitioning of respiration between host and symbiont in hospite. Yet, quantifying algal respiration within the animal is critical to the study of carbon/energy transfer between symbiotic partners (Muscatine et al., 1981, 1983; Steen and Muscatine, 1984; Davy et al., 1996, 2012). By measuring the activity of a key mitochondrial enzyme in the animal and its algal symbionts, this investigation represents a significant step forward in our understanding. In particular, to the best of our knowledge, this is the first time that the aerobic capacities of two algal symbiont species have been directly compared in the same host.

\section{mtDNA Copy Number as an Indicator of Mitochondrial Density}

For some organisms, the ratio between mitochondrial- and nuclear genomes serves as a proxy for mitochondrial density and, hence, aerobic capacity (e.g., Ballard and Melvin, 2007; Urschel and O'Brien, 2008). However, the mtDNA/nucDNA ratio was not a useful predictor of $E$. pallida respiration rate (as measured by $\mathrm{O}_{2}$ consumption) or aerobic capacity (as measured by citrate 

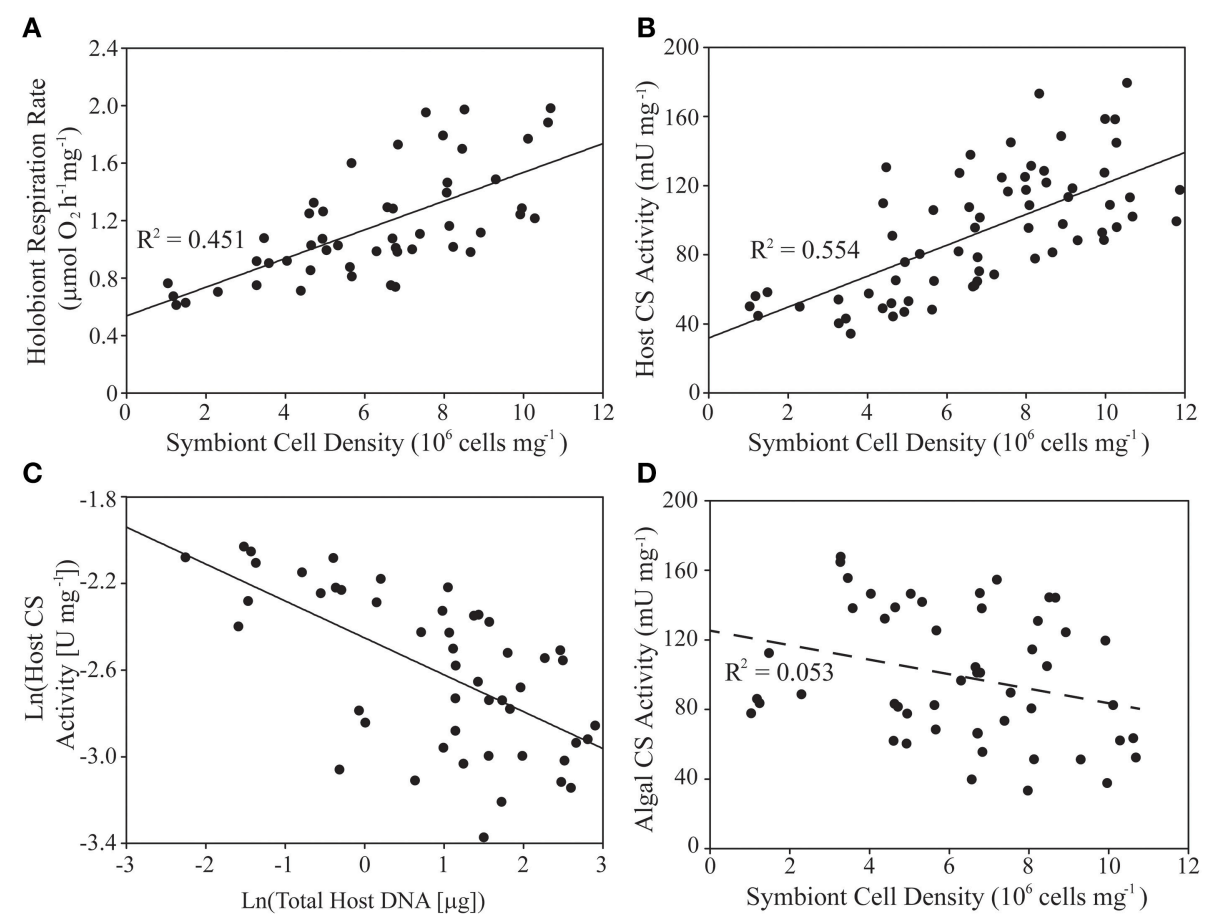

FIGURE 3 | Variability of holobiont respiration rate, animal host- and algal symbiont citrate synthase (CS) specific activities, host biomass, and symbiont density within a natural population of Exaiptasia pallida. (A,B,D) Linear regression analysis of algal symbiont density (cells mg ${ }^{-1}$ ) as a predictor of (A) holobiont respiration rate normalized to host protein content ( $\left.\mu \mathrm{mol} \mathrm{O}_{2} \mathrm{mg}^{-1} \mathrm{~h}^{-1}\right)$, (B) host CS specific activity $\left(U \mathrm{mg}{ }^{-1}\right)$, and (D) symbiont CS specific activity $(U$ $\mathrm{mg}^{-1}$ ). (C) Linear regression analysis of natural-log-transformed host biomass (mg protein) as a predictor of natural-log-transformed host CS specific activity $(\mathrm{U}$ $\mathrm{mg}^{-1}$ ). Relationships in $(\mathbf{A}-\mathbf{C})$ are statistically significant at $p<0.001(\mathbf{D}, p>0.05)$. See text for details of multiple regression analysis of the data in (B,C).

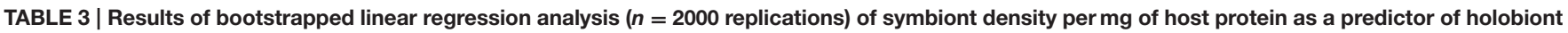
respiration rate normalized to host protein content ( $\left.\mu \mathrm{mol} \mathrm{O}_{2} \mathrm{mg}^{-1} \mathrm{~h}^{-1}\right)$, and host- and symbiont specific citrate synthase $(\mathrm{CS})$ activities $\left(\mathrm{U} \mathrm{mg}^{-1}\right)$.

\begin{tabular}{|c|c|c|c|c|c|c|}
\hline Dependent & Parameter & Value $(95 \% \mathrm{Cl})$ & $t$ & $P(t)$ & $F(d f)$ & $p(F)$ \\
\hline \multirow[t]{2}{*}{ Holobiont respiration rate } & Slope & $0.100(0.075,0.125)$ & 5.106 & $<0.0001$ & $41.173(1,49)$ & $<0.0001$ \\
\hline & Intercept & $0.537(0.403,0.668)$ & 6.417 & $<0.0001$ & & \\
\hline \multirow[t]{2}{*}{ Host CS activity } & Slope & $0.009(0.007,0.011)$ & 7.993 & $<0.0001$ & $63.89(1,67)$ & $<0.0001$ \\
\hline & Intercept & $0.037(0.01,0.063)$ & 3.747 & 0.0004 & & \\
\hline \multirow[t]{2}{*}{ Symbiont CS activity } & Slope & $-0.004(-0.006,0.000)$ & -1.940 & 0.058 & $3.745(1,49)$ & 0.0131 \\
\hline & Intercept & $0.125(0.107,0.165)$ & 9.130 & $<0.0001$ & & \\
\hline
\end{tabular}

Bold values indicate statistical significance at $p<0.05$.

synthase activity). The high variability of mtDNA/nucDNA ratios was surprising. However, if mitochondrial copy number ratio is heritable (Ding et al., 2015), this variability may reflect a high genetic diversity within our E. pallida population. Preliminary analysis of microsatellite loci as described by Hoadley et al. (2015) suggested that at least $60 \%$ of our anemones were genetically distinct individuals (data not shown). Likewise, anemone size was also highly variable in our natural population (range $0.1-$ $2.0 \mathrm{mg}$ total soluble protein) and mtDNA/nucDNA can vary with age (Simonetti et al., 1992; Barazzoni et al., 2000). Further work is clearly needed before we can conclude whether mtDNA copy number is a useful marker of mitochondrial density in anthozoans. Declining mtDNA/nucDNA ratio can indicate oxidative stress-induced mtDNA damage (Liu et al., 2003; Ballard and Melvin, 2007; Hunter et al., 2010), and this might be a useful application of the technique in symbiotic cnidarians, where oxidative stress can be a significant component of physiological dysfunction (Weis, 2008).

\section{Partitioning of Respiration between Symbiotic Partners}

\section{Variability in a Naturally Symbiotic Sea Anemone} Population

We noted two main trends in using CS activity as a marker of aerobic respiration in a natural population of E. pallida. Firstly, protein-normalized holobiont respiration rates and host CS specific activity decreased with increasing anemone biomass in a manner similar to that reported by Verde and McCloskey (1996) and Thuesen and Childress (1994) in benthic and 


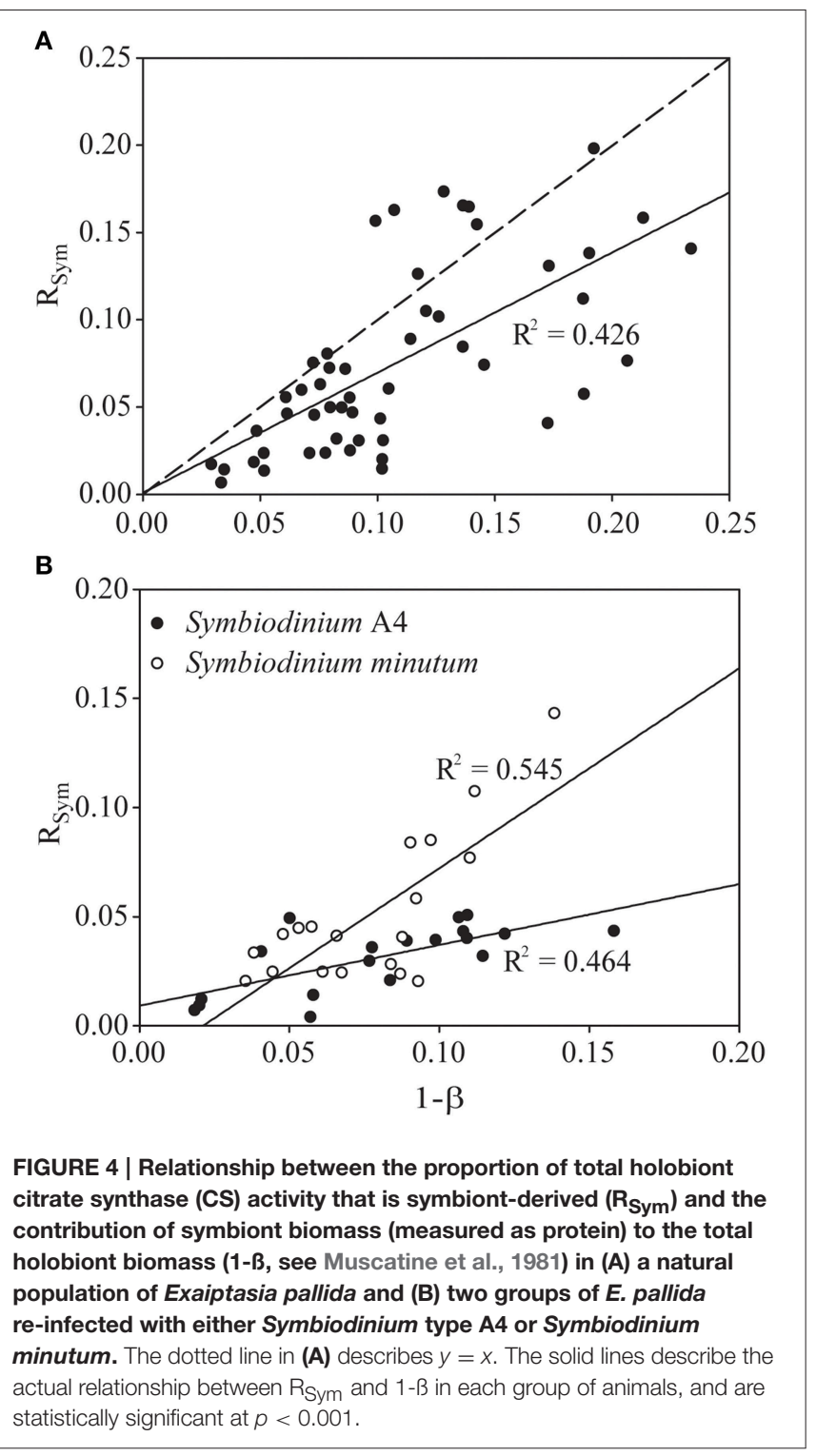

planktonic scyphozoans. We also found positive associations between symbiont density and both holobiont respiration rate and host CS specific activity. A positive relationship between holobiont respiration rate and increasing algal symbiont density is common in symbiotic cnidarians (Hoegh-Guldberg and Hinde, 1986; Hoogenboom et al., 2010; Starzak et al., 2014), although not ubiquitous (see Hoegh-Guldberg and Smith, 1989). This has been interpreted as the increasing contribution of algal symbiont respiration, and has been used to estimate algal respiration rate via regression analysis (Hoogenboom et al., 2010 and references therein). However, this interpretation assumes a constant rate of animal host respiration across changing algal densities. The coupling of host CS activity with symbiont density suggests that such an assumption would be incorrect for the E. pallida used here. Agostini et al. (2013) reported a positive correlation between symbiont density and holobiont electron transport system activity and hypothesized that this reflected an increased availability of respiratory substrates. We might also expect host
TABLE 4 | Comparison of respiratory and photosynthetic parameters in experimentally re-infected Exaiptasia pallida anemones.

\begin{tabular}{|c|c|c|}
\hline Variable & Test statistic & $p$ \\
\hline Symbiont density (cells $\left.\mathrm{mg}^{-1}\right)^{\ddagger}$ & $t=2.289$ & 0.028 \\
\hline Photosynthetic output ( $\mu \mathrm{mol} \mathrm{O}_{2} \mathrm{~h}^{-1} \mathrm{cell}^{-1}$ ) & $t=-2.701$ & 0.010 \\
\hline Holobiont respiration rate $\left(\mu \mathrm{mol} \mathrm{O}_{2} \mathrm{~h}^{-1} \mathrm{mg}^{-1}\right)^{\ddagger}$ & $t=2.329$ & 0.026 \\
\hline Host citrate synthase activity $\left(\mathrm{U} \mathrm{mg}^{-1}\right)$ & $t=-1.995$ & 0.054 \\
\hline Symbiont citrate synthase activity $\left(\mathrm{U} \mathrm{mg}^{-1}\right)^{\dagger}$ & $W=79$ & 0.002 \\
\hline $\mathrm{R}_{\text {Sym }}$ (dimensionless) $^{\dagger}$ & $W=128$ & 0.130 \\
\hline 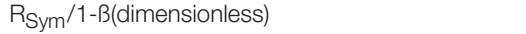 & $t=-2.615$ & 0.013 \\
\hline
\end{tabular}

Bold values indicate statistical significance at $p<0.05$.

$R_{\text {Sym }}$ and 1- $\beta$ are as defined in the text.

No symbol: $t$-test on raw data, $d f=36 ;{ }^{\dagger}$ Wilcoxon Rank Sum test, ${ }^{\ddagger} t$-test on $\log _{10^{-}}$ transformed data, $d f=36$

respiration to increase with symbiont density due to demands on host carbonic anhydrase to provide inorganic carbon to the algae (Weis, 1993; Hopkinson et al., 2015). Equally, higher host respiration rates could promote symbiont population growth through elevated tissue $\mathrm{CO}_{2}$ concentrations (Wooldridge, 2014). Regardless of the mechanistic link between holobiont respiration and algal symbiont density, our findings mean that correlations between these two variables should be interpreted with caution, since they likely reflect changes in the respiration of both symbiotic partners.

The results presented here have implications for the generality of one of the central assumptions for calculating CZAR - the contribution of Symbiodinium to animal respiration. Specifically, in-vivo respiration rates of animal and alga are assumed to be proportional to their respective biomasses (measured as protein content and designated $\beta$ and 1- $\beta$, respectively) (Muscatine et al., $1981,1983)$, and this proportionality is generally assumed to be 1:1 (e.g., Fitt and Pardy, 1981; Muller-Parker, 1984; Steen and Muscatine, 1984; Starzak et al., 2014). However, we noted a positive association between anemone specific CS activity and Symbiodinium cell density, and furthermore, a significant negative correlation between animal- and algal specific CS activities. Together, these findings suggest that as the proportion of symbiont biomass increases, the contribution of algal symbiont CS to holobiont CS (i.e., the "symbiont respiration fraction," defined here as $\mathrm{R}_{\text {Sym }}$ ) might increase at a slower rate. Indeed, in our natural E. pallida population, $\mathrm{R}_{\text {Sym }}$ was $31 \%$ [ $\pm 20 \%(95 \%$ $\mathrm{CI})$ ] lower than would have been expected from the assumption $\mathrm{R}_{\text {Sym }}=1-\beta$. Such an assumption would in this instance lead to overestimation of algal symbiont respiration (and vice versa for the animal host), potentially confounding the analysis of organic carbon translocation from symbiont to host. In short, the finding that $R_{\text {Sym }} \neq 1-\beta$ questions the validity of studies applying the growth rate method to determine carbon budgets in animal-algal symbioses (Muscatine et al., 1981, 1983; Falkowski et al., 1984; Verde and McCloskey, 1996; Levas et al., 2013; Starzak et al., 2014).

\section{Effect of Holobiont Composition on the Partitioning of Respiratory Activity between Symbiotic Partners}

Respiration rates vary between different holobionts (Verde and McCloskey, 1996; Agostini et al., 2013; Starzak et al., 2014; 

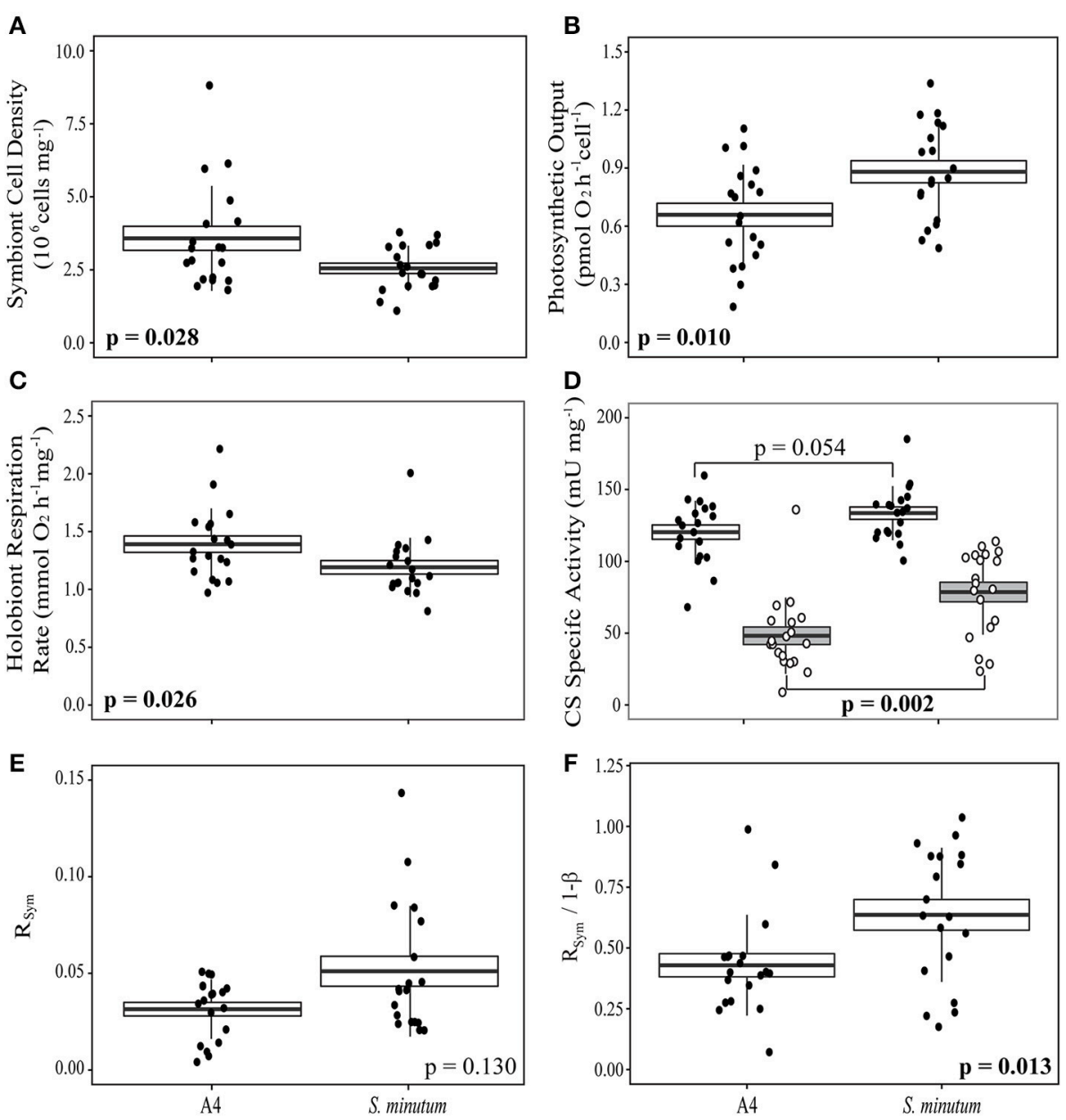

FIGURE 5 | Patterns of respiration and photosynthesis in two groups of Exaiptasia pallida experimentally re-infected with homologous Symbiodinium ITS2-type A4 or heterologous, ITS2-type B1 S. minutum, respectively. (A) Symbiont cell densities $\left(10^{6} \mathrm{cells} \mathrm{mg}^{-1}\right)$; (B) Symbiont photosynthetic output (pmol $\mathrm{O}_{2}$ cell $\left.^{-1} \mathrm{~h}^{-1}\right)$; (C) Holobiont respiration rate normalized to host protein content $\left(\mu \mathrm{mol} \mathrm{O}_{2} \mathrm{mg}^{-1} \mathrm{~h}^{-1}\right)$; (D) Host (white box, black markers) and symbiont (gray box, white markers) specific citrate synthase (CS) activities $\left(\mathrm{mU} \mathrm{mg}^{-1}\right)$; (E) The proportion of symbiont-derived CS activity relative to total holobiont CS activity (RSym); (F) The relationship between $R_{S y m}$ and symbiont biomass as a fraction of total biomass (1-B; Muscatine et al., 1981). Boxes represent means (thick black line) \pm 1 standard error, whiskers represent 1 standard deviation. Between-group comparisons for data in (A-C,F), and host CS specific activity in (D), were conducted using t-tests. Between-group comparisons for symbiont CS specific activity (D) and $\mathrm{R}_{\text {Sym }}$ (E) were conducted using Wilcoxon Rank-Sum tests.

Hoogenboom et al., 2015) and, in our re-infected E. pallida, were slightly lower (ca. 10\%) in animals hosting S. minutum than in animals associating with Symbiodinium A4. To some degree this must reflect a lower $S$. minutum population density within the host, which itself likely reflects the heterologous nature of the S. minutum symbiont. Photosynthesis per alga, however, was higher in S. minutum than in Symbiodinium A4 and, ordinarily, this would be interpreted alongside holobiont respiration, algal biomass and growth rates, in order to calculate CZAR and estimate symbiont-host carbon flux. Yet, higher CS activity in S. minutum suggests that this symbiont species was both respiring and photosynthesizing to a greater degree than was Symbiodinium A4. Thus, one should be cautious in interpreting higher rates of photosynthetic $\mathrm{O}_{2}$ evolution in $S$. minutum as evidence for a greater pool of fixed carbon available for translocation to the host.

Returning to the assumption $\mathrm{R}_{\mathrm{Sym}}=1-\beta$ (Muscatine et al., 1981 ), we noted that values for $1-\beta$ were similar for anemones hosting Symbiodinium A4 and S. minutum. That this is the case despite the lower symbiont densities in the latter association might be due to slightly, but not significantly, higher protein content per cell in S. minutum [mean: $38 \pm 4$ (SE) pg cell ${ }^{-1}$ ] relative to Symbiodinium A4 [29 \pm 4 (SE) pg cell $\left.{ }^{-1}\right]$. The effect of the near-equivalency of $1-\beta$ in the context of the symbionts' differing aerobic capacities (measured as CS activity) is that the relationship between $\mathrm{R}_{S y m}$ and 1- $ß$ differs significantly between the two holobionts (Figures $4 \mathbf{B}, \mathbf{5 F}$ ). In short, for the same proportion of biomass, $S$. minutum accounts for more of the total aerobic capacity of the holobiont than does Symbiodinium A4.

\section{Limitations of a Biochemical Approach to Quantifying Respiration}

We acknowledge the limitations in using metabolic enzymes as markers of respiration in an endosymbiosis. While we have demonstrated that the adequate separation of animal host and 
algal symbiont material is possible when working with $E$. pallida, applying these techniques to reef corals could be more challenging due to high mucus contents and the presence of an internal skeleton. A further limitation is the specificity of the selected enzyme(s), as many mitochondrial enzymes have secondary roles that are unrelated to respiration (e.g., fumarase is involved in cytosolic responses to DNA damage; Yogev et al., 2010). We cannot discount the influence of alternate metabolic pathways on the CS activities observed here, but the strong association between CS activity and $\mathrm{O}_{2}$ consumption suggests that this enzyme remains a useful marker for respiratory function. Reliable enzyme assays require that the enzymecatalyzed reaction is carefully controlled and usually enzymelimited. However, under natural conditions the metabolic enzymes of marine invertebrates are often present in excess so that the organisms can respond rapidly to changes in energy needs, trophic state, or the surrounding environment (Båmstedt, 1980; Martinez-Cruz et al., 2012). Thus, the same reaction invivo is more likely to be substrate-limited. Concretely, changes in CS activity as measured here reflect changes in the density of mitochondria or in the CS-contents of individual mitochondria (Spinazzi et al., 2012). The CS assay as applied here cannot detect short-term changes in respiration rate such as those resulting from the transfer of a photosynthetic organism from the dark to the light. Therefore, our data do not address the first assumption of the CZAR calculations - that animal host respiration rate in symbiotic cnidarians is unchanged upon illumination (Muscatine et al., 1981).

\section{Summary and Conclusions}

Here we describe a novel approach to addressing the question of how respiratory activity is partitioned between animal host and algal symbiont in the cnidarian-dinoflagellate association. Our quantification of mitochondrial genome copy number as a predictor of mitochondrial density was less informative than we expected, but such an approach is worthy of more attention in a clonal population or in individuals undergoing stress. By contrast, measurement of mitochondrial citrate synthase activity revealed interesting patterns in host- and symbiont aerobic capacity within and between different holobionts. Firstly, we can confirm a positive association between algal symbiont density and host aerobic capacity. Secondly, we noted that aerobic capacity of Symbiodinium cells in hospite was correlated negatively with that of their host and that different Symbiodinium

\section{REFERENCES}

Agostini, S., Fujimura, H., Fujita, K., Suzuki, Y., and Nakano, Y. (2013). Respiratory electron transport system activity in symbiotic corals and its link to calcification. Aquat. Biol. 18, 125-139. doi: 10.3354/ab00496

Akimoto, H., Kinumi, T., and Ohmiya, Y. (2005). Circadian rhythm of a TCA cycle enzyme is apparently regulated at the translational level in the dinoflagellate Lingulodinium polyedrum. J. Biol. Rhythms 20, 479-489. doi: $10.1177 / 0748730405280811$

Al-Sofyani, A. A., and Floos, Y. A. M. (2013). Effect of temperature on two reef-building corals Pocillopora damicornis and P. verrucosa in the Red Sea. Oceanologia 55, 917-935. doi: 10.5697/oc.55-4.917 species can have different aerobic capacities. To our knowledge, this is the first observation of differential in-hospite respiratory function between different Symbiodinium species in the same host animal. Perhaps most importantly, our data show that relying on symbiont biomass as the sole indicator of symbiont respiration can lead to inaccurate determination of respiratory partitioning within a single holobiont. Moreover, interspecific differences in algal respiration mean that this inaccuracy can vary between different holobionts. We therefore suggest that biochemical quantification of mitochondrial function should be considered when investigating respiratory function in different host-symbiont associations or under different environmental conditions.

\section{AUTHOR CONTRIBUTIONS}

TH and MW conceived the experiments, hypotheses, and analytical methods. TH carried out the experimental work with assistance from $\mathrm{JH}$ and $\mathrm{KH}$. $\mathrm{TH}, \mathrm{JH}$, and $\mathrm{KH}$ constructed the wet-lab facilities and maintained the anemone populations. $\mathrm{KH}$ constructed and programmed the custom-built LEDrespirometry system. $\mathrm{TH}$ analyzed the data and wrote the manuscript. $\mathrm{MW}, \mathrm{JH}, \mathrm{KH}$, and AM provided critical appraisal of the manuscript, statistical analyses and principal conclusions.

\section{FUNDING}

This research was funded by the National Science Foundation (grant no. 1316055).

\section{ACKNOWLEDGMENTS}

The authors wish to thank Dr. William Fitt for his donation of the anemones, and Dr. Mary-Alice Coffroth for providing the Pk702 $S$. minutum culture. We thank Dr. Tye Pettay for assistance with molecular characterization of the $S$. minutum culture, Dr. Kathryn Coyne for use of the AB7500 QPCR cycler, and Dr. Robert Trench for his constructive comments on the manuscript.

\section{SUPPLEMENTARY MATERIAL}

The Supplementary Material for this article can be found online at: http://journal.frontiersin.org/article/10.3389/fphys. 2016.00128 
Båmstedt, U. (1980). ETS activity as an estimator of respiratory rate of zooplankton populations. The significance of variations in environmental factors. J. Exp. Mar. Biol. Ecol. 42, 267-283. doi: 10.1016/0022-0981(80)90181-1

Barazzoni, R., Short, K. R., and Nair, K. S. (2000). Effects of aging on mitochondrial DNA copy number and cytochrome c oxidase gene expression in rat skeletal muscle, liver, and heart. J. Biol. Chem. 275, 3343-3347. doi: $10.1074 /$ jbc.275.5.3343

Baumgarten, S., Simakov, O., Esherick, L. Y., Liew, Y. J., Lehnert, E. M., Michell, C. T., et al. (2015). The genome of Aiptasia, a sea anemone model for coral symbiosis. Proc. Natl. Acad. Sci. U.S.A. 112, 11893-11898. doi: 10.1073/pnas.1513318112

Bellucci, J. L. (2004). The Effects of Seasonal Change on Copepods and Euphausiids off the Western Antarctic Peninsula: Results from Biochemical Assays and Respiration Studies. MS, University of South Florida.

Berg, J. M., Tymoczko, J. L., and Stryer, L. (2002). Biochemistry, 5th Edn. New York, NY: W H Freeman.

Burris, J. E. (1977). Photosynthesis, photorespiration, and dark respiration in eight species of algae. Mar. Biol. 39, 371-379. doi: 10.1007/BF00391940

Clarke, M. E., and Walsh, P. J. (1993). Effect of nutritional status on citrate synthase activity in Acartia tonsa and Temora longicornis. Limnol. Oceanogr. 38, 414-418. doi: 10.4319/lo.1993.38.2.0414

Cook, C. B., D'Elia, C. F., and Muller-Parker, G. (1988). Host feeding and nutrient sufficiency for zooxanthellae in the sea anemone Aiptasia pallida. Mar. Biol. 98, 253-262. doi: 10.1007/BF00391203

Davies, P. S. (1991). Effect of daylight variations on the energy budgets of shallowwater corals. Mar. Biol. 108, 137-144. doi: 10.1007/BF01313481

Davy, S., and Cook, C. (2001). The relationship between nutritional status and carbon flux in the zooxanthellate sea anemone Aiptasia pallida. Mar. Biol. 139, 999-1005. doi: 10.1007/s002270100640

Davy, S. K., Allemand, D., and Weis, V. M. (2012). The cell biology of cnidarian-dinoflagellate symbiosis. Microbiol. Mol. Biol. Rev. 76, 229-261. doi: 10.1128/MMBR.05014-11

Davy, S. K., Lucas, I. A. N., and Turner, J. R. (1996). Carbon budgets in temperate anthozoan-dinoflagellate symbioses. Mar. Biol. 126, 773-783. doi: 10.1007/BF00351344

De Wit, P., Dupont, S., and Thor, P. (2015). Selection on oxidative phosphorylation and ribosomal structure as a multigenerational response to ocean acidification in the common copepod Pseudocalanus acuspes. Evol. Appl. doi: 10.1111/eva.12335. [Epub ahead of print].

Ding, J., Sidore, C., Butler, T. J., Wing, M. K., Qian, Y., Meirelles, O., et al. (2015). Assessing mitochondrial DNA variation and copy number in lymphocytes of $\sim 2,000$ sardinians using tailored sequencing analysis tools. PLoS Genet. 11:e1005306. doi: 10.1371/journal.pgen.1005549

Dixon, G. B., Davies, S. W., Aglyamova, G. A., Meyer, E., Bay, L. K., and Matz, M. V. (2015). Genomic determinants of coral heat tolerance across latitudes. Science 348, 1460-1462. doi: 10.1126/science.1261224

Douglas, A. E. (2010). The Symbiotic Habit. Princeton, NJ: Princeton University Press.

Dunn, S. R., Pernice, M., Green, K., Hoegh-Guldberg, O., and Dove, S. G. (2012). Thermal stress promotes host mitochondrial degradation in symbiotic cnidarians: Are the batteries of the reef going to run out? PLOS ONE 7:e39024. doi: 10.1371/journal.pone.0039024

Dustan, P. (1982). Depth-dependent photoadaption by zooxanthellae of the reef coral Montastrea annularis. Mar. Biol. 68, 253-264. doi: 10.1007/BF004 09592

Edmunds, P. J., and Davies, P. S. (1988). Post-illumination stimulation of respiration rate in the coral Porites porites. Coral Reefs 7, 7-9. doi: $10.1007 / \mathrm{BF} 00301975$

Ernst, O., and Zor, T. (2010). Linearization of the Bradford protein assay. J. Vis. Exp. 38:e1918. doi: 10.3791/1918

Falkowski, P. G., Dubinsky, Z., Muscatine, L., and Porter, J. W. (1984). Light and the bioenergetics of a symbiotic coral. Bioscience 34, 705-709. doi: $10.2307 / 1309663$

Fitt, W. K., and Cook, C. B. (2001). Photoacclimation and the effect of the symbiotic environment on the photosynthetic response of symbiotic dinoflagellates in the tropical marine hydroid Myrionema amboinense. J. Exp. Mar. Biol. Ecol. 256, 15-31. doi: 10.1016/S0022-0981(00)00302-6
Fitt, W. K., and Pardy, R. L. (1981). Effects of starvation, and light and dark on the energy metabolism of symbiotic and aposymbiotic sea anemones, Anthopleura elegantissima. Mar. Biol. 61, 199-205. doi: 10.1007/BF00386660

Fitt, W. K., Pardy, R. L., and Littler, M. M. (1982). Photosynthesis, respiration, and contribution to community productivity of the symbiotic sea anemone Anthopleura elegantissima (Brandt, 1835). J. Exp. Mar. Biol. Ecol. 61, 213-232. doi: 10.1016/0022-0981(82)90070-3

Gattuso, J. P., Yellowlees, D., and Lesser, M. P. (1993). Depth- and lightdependent variation of carbon partitioning and utilization in the zooxanthellate scleractinian coral Stylophora pistillata. Mar. Ecol. Prog. 92, 267-276.

Goiran, C., Allemand, D., and Galgani, I. (1997). Transient Na+ stress in symbiotic dinoflagellates after isolation from coral-host cells and subsequent immersion in seawater. Mar. Biol. 129, 581-589. doi: 10.1007/s002270050199

Goiran, C., Al-Moghrabi, S., Allemand, D., and Jaubert, J. (1996). Inorganic carbon uptake for photosynthesis by the symbiotic coral/dinoflagellate association I. Photosynthetic performances of symbionts and dependence on sea water bicarbonate. J. Exp. Mar. Biol. Ecol. 199, 207-225.

Grajales, A., and Rodriguez, E. (2014). Morphological revision of the genus Aiptasia and the family Aiptasiidae (Cnidaria, Actiniaria, Metridioidea). Zootaxa 3826, 55-100. doi: 10.11646/zootaxa.3826.1.2

Grottoli, A. G., Rodrigues, L. J., and Palardy, J. E. (2006). Heterotrophic plasticity and resilience in bleached corals. Nature 440, 1186-1189. doi: 10.1038/nature04565

Guderley, H., and Johnston, I. I. (1996). Plasticity of fish muscle mitochondria with thermal acclimation. J. Exp. Biol. 199, 1311-1317.

Guillard, R. R. L. (1973). "Division rates," in Handbook of Phycological Methods, ed Stein (Cambridge: Cambridge University Press), 289-312.

Guo, W., Jiang, L., Bhasin, S., Khan, S. M., and Swerdlow, R. H. (2009). DNA extraction procedures meaningfully influence qPCR-based mtDNA copy number determination. Mitochondrion 9, 261-265. doi: 10.1016/j.mito.2009.03.003

Harland, A. D., and Davies, P. S. (1995). Symbiont photosynthesis increases both respiration and photosynthesis in the symbiotic sea anemone Anemonia viridis. Mar. Biol. 123, 715-722. doi: 10.1007/BF00349114

Hawkins, T. D., Bradley, B. J., and Davy, S. K. (2013). Nitric oxide mediates coral bleaching through an apoptotic-like cell death pathway: evidence from a model cnidarian-dinoflagellate symbiosis. FASEB J. 27, 4790-4798. doi: 10.1096/fj.13235051

Hawkins, T. D., Krueger, T. K., Becker, S., Fisher, P. L., and Davy, S. K. (2014). Differential nitric oxide synthesis and host apoptotic events correlate with bleaching susceptibility in reef corals. Coral Reefs 33, 141-153. doi: 10.1007/s00338-013-1103-4

Henry, L. V., and Torres, J. J. (2013). Metabolism of an Antarctic solitary coral, Flabellum impensum. J. Exp. Mar. Biol. Ecol. 449, 17-21. doi: 10.1016/j.jembe.2013.08.010

Hoadley, K. D., Rollison, D., Pettay, D. T., and Warner, M. E. (2015). Differential carbon utilization and asexual reproduction under elevated $\mathrm{pCO} 2$ conditions in the model anemone, Exaiptasia pallida, hosting different symbionts. Limnol. Oceanogr. 60, 2108-2120. doi: 10.1002/lno.10160

Hoadley, K. D., Szmant, A. M., and Pyott, S. J. (2011). Circadian clock gene expression in the coral favia fragum over diel and lunar reproductive cycles. PLoS ONE 6:e19755. doi: 10.1371/journal.pone.0019755

Hoegh-Guldberg, O., and Hinde, R. (1986). Studies on a nudibranch that contains zooxanthellae I. Photosynthesis, respiration and the translocation of newly fixed carbon by zooxanthellae in Pteraeolidia ianthina. Proc. R. Soc. Lond. B Biol. Sci. 228, 493-509.

Hoegh-Guldberg, O., and Smith, G. (1989). Influence of the population density of zooxanthellae and supply of ammonium on the biomass and metabolic characteristics of the reef corals Seriatopora hystrix and Stylophora pistillata. Mar. Ecol. Prog. Ser. 57, 173-186. doi: 10.3354/meps057173

Hofmann, D. K., and Kremer, B. P. (1981). Carbon metabolism and strobilation in Cassiopea andromedea (Cnidaria: Scyphozoa): Significance of endosymbiotic dinoflagellates. Mar. Biol. 65, 25-33. doi: 10.1007/BF00397064

Hoogenboom, M., Beraud, E., and Ferrier-Pagès, C. (2010). Relationship between symbiont density and photosynthetic carbon acquisition in the temperate coral Cladocora caespitosa. Coral Reefs 29, 21-29. doi: 10.1007/s00338-0090558-9 
Hoogenboom, M., Rottier, C., Sikorski, S., and Ferrier-Pagès, C. (2015). Amongspecies variation in the energy budgets of reef-building corals: scaling from coral polyps to communities. J. Exp. Biol. 218, 3866-3877. doi: 10.1242/jeb. 124396

Hopkinson, B. M., Tansik, A. L., and Fitt, W. K. (2015). Internal carbonic anhydrase activity in the tissue of scleractinian corals is sufficient to support proposed roles in photosynthesis and calcification. J. Exp. Biol. 218, 2039-2048. doi: $10.1242 /$ jeb.118182

Hughes, A. D., Grottoli, A. G., Pease, T. K., and Matsui, Y. (2010). Acquisition and assimilation of carbon in non-bleached and bleached corals. Mar. Ecol. Prog. Ser. 420, 91-101. doi: 10.3354/meps08866

Hunter, S. E., Jung, D., Di Giulio, R. T., and Meyer, J. N. (2010). The QPCR assay for analysis of mitochondrial DNA damage, repair, and relative copy number. Methods 51, 444-451. doi: 10.1016/j.ymeth.2010.01.033

Jacques, T. G., Marshall, N., and Pilson, M. E. Q. (1983). Experimental ecology of the temperate scleractinian coral Astrangia danae. Mar. Biol. 76, 135-148. doi: $10.1007 /$ BF00392730

Kawall, H., Torres, J., and Geiger, S. (2001). "Effects of the ice-edge bloom and season on the metabolism of copepods in the Weddell Sea, Antarctica," in Copepoda: Developments in Ecology, Biology and Systematics, eds R. Lopes, J. Reid, and C. F. Rocha (Curibita: Springer), 67-77.

Kibbe, W. A. (2007). OligoCalc: an online oligonucleotide properties calculator. Nucleic Acids Res. 35, W43-W46. doi: 10.1093/nar/gkm234

Kopp, C., Domart-Coulon, I., Escrig, S., Humbel, B. M., Hignette, M., and Meibom, A. (2015). Subcellular investigation of photosynthesis-driven carbon assimilation in the symbiotic reef coral Pocillopora damicornis. mBio 6:e2299-14. doi: 10.1128/mBio.02299-14

LaJeunesse, T. C. (2002). Diversity and community structure of symbiotic dinoflagellates from Caribbean coral reefs. Mar. Biol. 141, 387-400. doi: 10.1007/s00227-002-0829-2

Leal, M. C., Hoadley, K., Pettay, D. T., Grajales, A., Calado, R., and Warner, M. E. (2015). Symbiont type influences trophic plasticity of a model cnidarian-dinoflagellate symbiosis. J. Exp. Biol. 218, 858-863. doi: 10.1242/jeb. 115519

Levas, S. J., Grottoli, A. G., Hughes, A., Osburn, C. L., and Matsui, Y. (2013). Physiological and biogeochemical traits of bleaching and recovery in the mounding species of coral Porites lobata: Implications for resilience in mounding corals. PLoS ONE 8:e63267. doi: 10.1371/journal.pone.0063267

Liu, C. S., Tsai, C. S., Kuo, C. L., Chen, H. W., Lii, C. K., Ma, Y. S., et al. (2003). Oxidative stress-related alteration of the copy number of mitochondrial DNA in human leukocytes. Free Radic. Res. 37, 1307-1317. doi: $10.1080 / 10715760310001621342$

Lutz, A., Raina, J.-B., Motti, C. A., Miller, D. J., and van Oppen, M. J. H. (2015). Host coenzyme Q redox state is an early biomarker of thermal stress in the coral Acropora millepora. PLoS ONE 10:e0139290. doi: 10.1371/journal.pone. 0139290

Marsh, A. G., Leong, P. K., and Manahan, D. T. (1999). Energy metabolism during embryonic development and larval growth of an Antarctic sea urchin. J. Exp. Biol. 202, 2041-2050.

Martinez-Cruz, O., Sanchez-Paz, A., Garcia-Carreño, F., Jimenez-Gutierrez, L., and Muhlia-Almaza, A. (2012). "Invertebrates mitochondrial function and energetic challenges," in Bioenergetics, ed K. Clark (Rijeka: InTech), 181-218.

Matthews, J. L., Sproles, A. E., Oakley, C. A., Grossman, A. R., Weis, V. M., and Davy, S. K. (2015). Menthol-induced bleaching rapidly and effectively provides experimental aposymbiotic sea anemones (Aiptasia sp.) for symbiosis investigations. J. Exp. Biol. 219, 306-310. doi: 10.1242/jeb.128934

McCloskey, L. R., and Muscatine, L. (1984). Production and respiration in the red sea coral Stylophora pistillata as a function of depth. Proc. R. Soc. Lond. B Biol. Sci. 222, 215-230. doi: 10.1098/rspb.1984.0060

Miller, F. J., Rosenfeldt, F. L., Zhang, C., Linnane, A. W., and Nagley, P. (2003). Precise determination of mitochondrial DNA copy number in human skeletal and cardiac muscle by a PCR-based assay: lack of change of copy number with age. Nucleic Acids Res. 31, e61-e61. doi: 10.1093/nar/gng060

Moraes, C. T. (2001). What regulates mitochondrial DNA copy number in animal cells? Trends Genet. 17, 199-205. doi: 10.1016/S0168-9525(01)02238-7

Muller-Parker, G. (1984). Photosynthesis-irradiance responses and photosynthetic periodicity in the sea anemone Aiptasia pulchella and its zooxanthellae. Mar. Biol. 82, 225-232. doi: 10.1007/BF00392403
Muller-Parker, G., and Davy, S. K. (2001). Temperate and tropical algalsea anemone symbioses. Invert. Biol. 120, 104-123. doi: 10.1111/j.17447410.2001.tb00115.x

Muller-Parker, G., and D'Elia, C. F. (1997). "Interactions between corals and their symbiotic algae," in Life and Death of Coral Reefs, ed C. Birkeland (New York, NY: Chapmand \& Hall), 96-114.

Muscatine, L. (1990). "The role of symbiotic algae in carbon and energy flux in reef corals," in Coral Reefs, Ecosystemts of the World 25, ed Z. Dubinsky (Amsterdam: Elsevier), 75-87.

Muscatine, L., Falkowski, P., and Dubinsky, T. J. (1983). "Carbon budgets in symbiotic associations," in Endocytobiology II, eds W. Schwemmler and H. E. A. Schenk (Berlin: Walter de Gruyter), 649-658.

Muscatine, L., Falkowski, P. G., Porter, J. W., and Dubinsky, Z. (1984). Fate of photosynthetically fixed carbon in light-adapted and shade-adapted colonies of the symbiotic coral Stylophora pistillata. Proc. R. Soc. B Biol. Sci. 222, 181-202. doi: 10.1098/rspb.1984.0058

Muscatine, L., and Porter, J. W. (1977). Reef corals: mutualistic symbioses adapted to nutrient-poor environments. Bioscience 27, 454-460. doi: 10.2307/12 97526

Muscatine, L. R., McCloskey, L. E., and Marian, R. (1981). Estimating the daily contribution of carbon from zooxanthellae to coral animal respiration. Limnol. Oceanogr. 26, 601-611. doi: 10.4319/lo.1981.26.4.0601

Pace, D. A., Marsh, A. G., Leong, P. K., Green, A. J., Hedgecock, D., and Manahan, D. T. (2006). Physiological bases of genetically determined variation in growth of marine invertebrate larvae: a study of growth heterosis in the bivalve Crassostrea gigas. J. Exp. Mar. Biol. Ecol. 335, 188-209. doi: 10.1016/j.jembe.2006.03.005

Paxton, C. W., Davy, S. K., and Weis, V. M. (2013). Stress and death of host cells play a role in cnidarian bleaching. J. Exp. Biol. 216, 2813-2820. doi: 10.1242/jeb.087858

Pettay, D. T., and LaJeunesse, T. C. (2007). Microsatellites from clade B Symbiodinium spp. specialized for Caribbean corals in the genus Madracis. Mol. Ecol. Notes 7, 1271-1274.

Putnam, N. H., Srivastava, M., Hellsten, U., Dirks, B., Chapman, J., Salamov, A., et al. (2007). Sea anemone genome reveals ancestral eumetazoan gene repertoire and genomic organization. Science 317, 86-94. doi: 10.1126/science.1139158

Qiu, C., Hevner, K., Abetew, D., Sedensky, M., Morgan, P., Enquobahrie, D. A., et al. (2013). Mitochondrial DNA copy number and oxidative DNA damage in placental tissues from gestational diabetes and control pregnancies: A pilot study. Clin. Lab. 59, 655-660. doi: 10.7754/Clin.Lab.2012.120227

R Development Core Team (2015). R: A Language and Environment for Statistical Computing. Vienna: R Foundation for Statistical Computing. Available online at: http://www.R-project.org

Rivest, E. B., and Hofmann, G. E. (2014). Responses of the metabolism of the larvae of Pocillopora damicornis to ocean acidification and warming. PLOS ONE 9:e96172. doi: 10.1371/journal.pone.0096172

Sarkissian, I. V., and Boatwright, D. T. (1975). Influence of possible in situ ionic environment on kinetics of purified citrate synthase from an osmoconformer sea anemone, Bunedosoma cavernata. Enzyme 19, 110-115.

Schrameyer, V., Wangpraseurt, D., Hill, R., Kühl, M., Larkum, A. W. D., and Ralph, P. J. (2014). Light respiratory processes and gross photosynthesis in two scleractinian corals. PLoS ONE 9:e110814. doi: 10.1371/journal.pone.0110814

Shama, L. N. S., Strobel, A., Mark, F. C., and Wegner, K. M. (2014). Transgenerational plasticity in marine sticklebacks: maternal effects mediate impacts of a warming ocean. Funct. Ecol. 28, 1482-1493. doi: 10.1111/13652435.12280

Simonetti, S., Chen, X., DiMauro, S., and Schon, E. A. (1992). Accumulation of deletions in human mitochondrial DNA during normal aging: analysis by quantitative PCR. Biochim. Biophys. Acta 1180, 113-122. doi: 10.1016/09254439(92)90059-V

Sorek, M., Yacobi, Y. Z., Roopin, M., Berman-Frank, I., and Levy, O. (2013). Photosynthetic circadian rhythmicity patterns of Symbiodinium, the coral endosymbiotic algae. Proc. R. Soc. B 280, 20122942. doi: 10.1098/rspb.2013.1012

Spinazzi, M., Casarin, A., Pertegato, V., Ermani, M., Salviati, L., and Angelini, C. (2011). Optimization of respiratory chain enzymatic assays in muscle for the diagnosis of mitochondrial disorders. Mitochondrion 11, 893-904. doi: 10.1016/j.mito.2011.07.006 
Spinazzi, M., Casarin, A., Pertegato, V., Salviati, L., and Angelini, C. (2012). Assessment of mitochondrial respiratory chain enzymatic activities on tissues and cultured cells. Nat. Protoc. 7, 1235-1246. doi: 10.1038/nprot.2012.058

Srere, P. A. (1969). Citrate synthase. Methods Enzymol. 13, 3-11. doi: 10.1016/0076-6879(69)13005-0

Starzak, D. E., Quinnell, R. G., Nitschke, M. R., and Davy, S. K. (2014). The influence of symbiont type on photosynthetic carbon flux in a model cnidariandinoflagellate symbiosis. Mar. Biol. 161, 711-724. doi: 10.1007/s00227-0132372-8

Stat, M., Morris, E., and Gates, R. D. (2008). Functional diversity in coraldinoflagellate symbiosis. Proc. Natl. Acad. Sci. U.S.A. 105, 9256-9261. doi: 10.1073/pnas.0801328105

Steen, R. G., and Muscatine, L. (1984). Daily budgets of photosynthetically fixed carbon in symbiotic zoanthids. Biol. Bull. 167, 477-487. doi: 10.2307/1541292

Suggett, D. J., Warner, M. E., Smith, D. J., Davey, P., Hennige, S., and Baker, N. R. (2008). Photosynthesis and production of hydrogen peroxide by Symbiodinium (Pyrrhophyta) phylotypes with different thermal tolerances. J. Phycol. 44, 948-956. doi: 10.1111/j.1529-8817.2008.00537.x

Sunagawa, S., Wilson, E. C., Thaler, M., Smith, M. L., Caruso, C., Pringle, J. R., et al. (2009). Generation and analysis of transcriptomic resources for a model system on the rise: The sea anemone Aiptasia pallida and its dinoflagellate endosymbiont. BMC Genomics 10:258. doi: 10.1186/1471-2164-10-258

Thuesen, E. V., and Childress, J. J. (1994). Oxygen consumption rates and metabolic enzyme activities of oceanic California medusae in relation to body size and habitat depth. Biol. Bull. 187, 84-98. doi: 10.2307/1542168

Torres, J. J., Aarset, A. V., Donnelly, J., Hopkins, T. L., Lancraft, T. M., and Ainley, D. G. (1994). Metabolism of Antarctic micronektonic Crustacea as a function of depth of occurrence and season. Mar. Ecol. Prog. Ser. 113, 207-219. doi: 10.3354/meps113207

Tremblay, P., Grover, R., Maguer, J. F., Hoogenboom, M., and Ferrier-Pages, C. (2014). Carbon translocation from symbiont to host depends on irradiance and food availability in the tropical coral Stylophora pistillata. Coral Reefs 33, 1-13. doi: 10.1007/s00338-013-1100-7

Tremblay, P., Grover, R., Maguer, J. F., Legendre, L., and Ferrier-Pagès, C. (2012). Autotrophic carbon budget in coral tissue: a new 13C-based model of photosynthate translocation. J. Exp. Biol. 215, 1384-1393. doi: 10.1242/jeb.065201

Trench, R. K. (1971). Physiology and biochemistry of zooxanthellae symbiotic with marine coelenterates. 1. Assimilation of photosynthetic products of zooxanthellae by two marine coelenterates. Proc. R. Soc. Lond. Ser. B Biol. Sci. $177,225$.

Tytler, E. M., and Trench, R. K. (1986). Activities of enzymes in betacarboxylation reactions and of catalase in cell-free preparations from the symbiotic dinoflagellates Symbiodinium spp. From a coral, a clam, a zoanthid and two sea anemones. Proc. R. Soc. Lond. B Biol. Sci. 228, 483-492.

Urschel, M. R., and O'Brien, K. M. (2008). High mitochondrial densities in the hearts of Antarctic icefishes are maintained by an increase in mitochondrial size rather than mitochondrial biogenesis. J. Exp. Biol. 211, 2638-2646. doi: 10.1242/jeb.018598
Verde, E. A., and McCloskey, L. R. (1996). Photosynthesis and respiration of two species of algal symbionts in the Anemone Anthopleura elegantissima (Brandt) (Cnidaria; Anthozoa). J. Exp. Mar. Biol. Ecol. 195, 187-202. doi: 10.1016/0022-0981(95)00080-1

Verde, E. A., and McCloskey, L. R. (1998). Production, respiration, and photophysiology of the mangrove jellyfish Cassiopea xamachana symbiotic with zooxanthellae: effect of jellyfish size and season. Mar. Ecol. Prog. Ser. 168, 147-162. doi: 10.3354/meps168147

Wang, J.-T., Chen, Y.-Y., Tew, K. S., Meng, P.-J., and Chen, C. A. (2012). Physiological and biochemical performances of menthol-induced aposymbiotic corals. PLOS ONE 7:e46406. doi: 10.1371/journal.pone. 0046406

Wang, J. T., Meng, P. J., Sampayo, E., Tang, S. L., and Chen, C. A. (2011) Photosystem II breakdown induced by reactive oxygen species in freshlyisolated Symbiodinium from Montipora (Scleractinia; Acroporidae). Mar. Ecol. Prog. Ser. 422, 51-62. doi: 10.3354/meps08913

Weis, V. M. (1993). Effect of dissolved inorganic carbon concentration on the photosynthesis of the symbiotic sea anemone Aiptasia pulchella Carlgren: Role of carbonic anhydrase. J. Exp. Mar. Biol. Ecol. 174, 209-225. doi: 10.1016/00220981(93)90018-J

Weis, V. M. (2008). Cellular mechanisms of cnidarian bleaching: stress causes the collapse of symbiosis. J. Exp. Biol. 211, 3059-3066. doi: 10.1242/jeb. 009597

Wooldridge, S. A. (2014). Differential thermal bleaching susceptibilities amongst coral taxa: re-posing the role of the host. Coral Reefs 33, 15-27. doi: 10.1007/s00338-013-1111-4

Wu, Z., Puigserver, P., Andersson, U., Zhang, C., Adelmant, G., Mootha, V., et al. (1999). Mechanisms controlling mitochondrial biogenesis and respiration through the thermogenic coactivator PGC-1. Cell 98, 115-124. doi: 10.1016/S0092-8674(00)80611-X

Yellowlees, D., Rees, T. A. V., and Leggat, W. (2008). Metabolic interactions between algal symbionts and invertebrates hosts. Plant Cell Environ. 31 679-694. doi: 10.1111/j.1365-3040.2008.01802.x

Yogev, O., Yogev, O., Singer, E., Shaulian, E., Goldberg, M., Fox, T. D., et al. (2010). Fumarase: a mitochondrial metabolic enzyme and a cytosolic/nuclear component of the DNA damage response. PLoS Biol. 8:e1000328. doi: 10.1371/journal.pbio. 1000328

Conflict of Interest Statement: The authors declare that the research was conducted in the absence of any commercial or financial relationships that could be construed as a potential conflict of interest.

Copyright (c) 2016 Hawkins, Hagemeyer, Hoadley, Marsh and Warner. This is an open-access article distributed under the terms of the Creative Commons Attribution License (CC BY). The use, distribution or reproduction in other forums is permitted, provided the original author(s) or licensor are credited and that the original publication in this journal is cited, in accordance with accepted academic practice. No use, distribution or reproduction is permitted which does not comply with these terms. 